\title{
Differential Expression of Munc13-2 Produces Unique Synaptic Phenotypes in the Basolateral Amygdala of C57BL/6J and DBA/2J Mice
}

\author{
Dominic A. Gioia, $\$ Nancy J. Alexander, and $\odot$ Brian A. McCool \\ Department of Physiology and Pharmacology, Wake Forest School of Medicine, Winston-Salem, North Carolina 27157
}

C57BL/6J (B6) and DBA/2J (D2) mice are well known to differentially express a number of behavioral phenotypes, including anxiety-like behavior, fear conditioning, and drug self-administration. However, the cellular mechanisms contributing to these differences remain unclear. Given the basolateral amygdala (BLA) contributes to these behaviors, we characterized strain-dependent differences in presynaptic and postsynaptic function in BLA neurons by integrating electrophysiological, biochemical, and genetic approaches to identify specific molecular mechanisms. We found that $\mathrm{D} 2$ glutamatergic synapses expressed enhanced release probability and lower sensitivity to both the inhibitory effects of low extracellular calcium and facilitation by phorbol esters. Furthermore, repetitive stimulation of BLA afferents at low $(2 \mathrm{~Hz})$ or high $(40 \mathrm{~Hz})$ frequencies revealed that $\mathrm{B} 6$ terminals, relative to $\mathrm{D} 2$ terminals, were more sensitive to synaptic fatigue principally because of reduced vesicle recycling rates. Additionally, B6 synapses exhibited more robust augmentation of spontaneous release after repetitive stimulation relative to the D2 strain. In silico analysis of the inheritance of synaptic physiology from an array of BXD recombinant inbred strains (Jansen et al., 2011) identified a segment on chromosome 4 containing the gene encoding Munc13-2, which has calcium-/phorbol ester-binding domains and controls presynaptic function. We subsequently found that B6 mice express substantially higher levels of Munc13-2 compared with the D2 strain whereas expression of several release-related proteins, including Munc13-1, was equivalent. We then knocked down the expression of Munc13-2 in B6 mice using a short hairpin RNA and found this recapitulated the presynaptic phenotype of D2 BLA synapses.

Key words: amygdala; glutamate; Munc13; presynaptic

Significance Statement

$\mathrm{DBA} / 2 \mathrm{~J}$ and C57BL/6J mice have been used to understand the genetic mechanisms controlling behaviors related to a number of psychiatric illnesses. However, the fundamental neurobiological mechanisms producing these behavioral characteristics remain unresolved. Here we identify a critical family of presynaptic proteins differentially expressed by these strains that control straindependent synaptic physiology. This family of proteins regulates excitation/secretion coupling, vesicle recycling, and short-term plasticity throughout the CNS. Thus, differential inheritance of proteins like Munc13-2 has broad implications for genetic control over a wide variety of pathological behaviors. Importantly, these proteins also contain a large number of modulatory sites, making them attractive potential targets for the development of novel neuropharmaceutical treatments.

\section{Introduction}

Inbred mouse strains have been widely used to model a number of psychiatric disorders as they provide a stable genetic background to test the cellular and behavioral effects of neu-

Received June 3, 2016; revised Aug. 5, 2016; accepted Aug. 28, 2016.

Author contributions:D.A.G. and B.A.M. designed research; D.A.G., N.J.A., and B.A.M. performed research;D.A.G., N.J.A., and B.A.M. analyzed data; D.A.G. and B.A.M. wrote the paper.

This work was supported by NIH Grants R01AA023999, R01AA014445, U01AA020942, and T32AA007565.

The authors declare no competing financial interests.

Correspondence should be addressed to Dr. Brian A. McCool at the above address. E-mail: bmccool@wakehealth.edu.

DOI:10.1523/JNEUROSCI.1785-16.2016

Copyright $\odot 2016$ the authors $\quad 0270-6474 / 16 / 3610964-14 \$ 15.00 / 0$ ropharmaceutical drugs. Comparison of multiple inbred strains and cross-breeding between these strains allows for powerful correlative gene $\times$ behavior analysis (Brigman et al., 2009), which potentially identifies candidate genes regulating specific behaviors. Additionally, recent advances in the ability of researchers to precisely manipulate the expression of specific genes, including gene knock-outs (Milner et al., 2015), RNA interference (Maiya et al., 2012), or gene overexpression (Kanatsou et al., 2016), allows for a greater understanding of how specific genes contribute to pathological conditions.

The DBA/2J (D2) and C57BL/6J (B6) mouse strains exhibit unique behavioral phenotypes that have been used to investigate the neurobiological mechanisms associated with affective disor- 
ders. For example, these strains express unique anxiety-like and depressive-like behaviors (Võikar et al., 2005; DuBois et al., 2006; Lad et al., 2010) as well as distinct responses to environmental stressors (Przewłocka et al., 1988; Tarricone et al., 1995; Hwang et al., 1999). Additionally, D2 and B6 mice show differences in the ability to assign emotional valence to positive and aversive stimuli (Waddell et al., 2004; Orsini et al., 2005). These strains also selfadminister abused drugs at different rates (Gill et al., 1996), display unique drug-seeking phenotypes (Orsini et al., 2008; Elmer et al., 2010), and exhibit distinct vulnerabilities to chronic drug exposure (Crabbe, 1998; McCool and Chappell, 2015). Strainspecific differences in synaptic function in these strains (DuBois et al., 2006; Mozhui et al., 2010) highlight potential synaptic mechanisms underlying many of these unique behavioral phenotypes. These strains can thus provide insight into the genetic mechanisms controlling the neurophysiological mechanisms related to the high comorbidity of substance abuse and affective disorders (Agnew-Blais and Danese 2016; Grant et al., 2016).

The amygdala regulates many of the unique behaviors distinguishing D2 and B6 strains. The lateral/basolateral amygdala (BLA) is the main input nucleus to the amygdala and receives highly processed sensory and executive information from cortical and subcortical regions. The BLA consists primarily of glutamatergic pyramidal cells ( $\sim 90 \%$ ), which send efferent projections to downstream anxiety- and reward-related brain regions integral for emotional learning. Decades of research have established that increasing BLA pyramidal cell activity produces anxiety-like behaviors (Sanders and Shekhar, 1991; Sajdyk et al., 1999b) whereas inhibiting pyramidal cell output produces anxiolytic-like effects (Pesold and Treit, 1995; Sanders and Shekhar, 1995; Sajdyk et al., 1999a), presumably through downstream modulation of the extended amygdala. More recent work has shown that regulation of BLA terminal fields in the nucleus accumbens can also robustly modulate reward-seeking behaviors (Stuber et al., 2011). Synaptic mechanisms regulating BLA pyramidal cell output within these strains could provide valuable information about neurophysiological mechanisms controlling a wide array of "psychiatric disorders" and aid in the development of novel medications.

Previous studies have found that presynaptic plasticity in BLA glutamatergic synapses occurs in response to environmental stressors (Adamec et al., 2001) and is critical for the development of fear and anxiety-like behaviors. Plasticity in medial prefrontal cortical (mPFC) projections to the BLA are necessary for fear learning and extinction (Tsvetkov et al., 2002; Cho et al., 2013; Arruda-Carvalho and Clem, 2014), and presynaptic plasticity at medial inputs to the BLA after chronic ethanol may facilitate withdrawal-associated anxiogenesis (Christian et al., 2013). Together, these studies highlight the importance of understanding presynaptic signaling in the BLA and suggest that this signaling may be particularly important for the development of pathological fear/anxiety. In the present study, we characterize unique glutamatergic synaptic phenotypes in B6 and D2 mice and identify the Munc13 family of vesicle priming proteins as potent regulators of presynaptic release and short-term plasticity within BLA circuitry. Our results suggest that differential expression of Munc13 isoforms may contribute to the different behavioral phenotypes observed in D2 and B6 mice.

\section{Materials and Methods}

\section{Animals}

Five-week-old male C57BL/6J (https://www.jax.org/strain/000664) and DBA/2J (https://www.jax.org/strain/000671) mice were obtained from The Jackson Laboratory and given access to food and water ad libitum.
Mice were group housed for 1-2 weeks in a facility maintained by institutional animal resource personnel with housing conditions consistent with the NIH Guidelines for the Care and Use of Laboratory Animals $\left(68-74^{\circ} \mathrm{F}, 30-70 \%\right.$ relative humidity) before the experiments. All experimental procedures were reviewed and approved by the Wake Forest School of Medicine Animal Care and Use Committee.

\section{Electrophysiology methods}

Slice preparation. Animals were anesthetized with isoflurane and decapitated. Brains were quickly removed and incubated in an ice-cold sucrose modified artificial CSF (aCSF) containing (in mM) 180 sucrose, $30 \mathrm{NaCl}$, $4.5 \mathrm{KCl}, 1 \mathrm{MgCl}_{2} \cdot 6 \mathrm{H}_{2} \mathrm{O}, 26 \mathrm{NaHCO}_{3}, 1.2 \mathrm{NaH}_{2} \mathrm{PO}_{4}, 0.10$ ketamine, and 10 glucose, equilibrated with $95 \% \mathrm{O}_{2}$ and $5 \% \mathrm{CO}_{2}$. Coronal slices containing the BLA were obtained $(300 \mu \mathrm{m})$ using a VT1200 S vibrating blade microtome (Leica) and were incubated for at least $1 \mathrm{~h}$ in roomtemperature $\left(\sim 25^{\circ} \mathrm{C}\right)$ oxygenated standard aCSF (in mM: $126 \mathrm{NaCl}, 3$ $\mathrm{KCl}, 1.25 \mathrm{NaH}_{2} \mathrm{PO}_{4}, 2 \mathrm{MgSO}_{4}, 2 \mathrm{CaCl}_{2}, 26 \mathrm{NaHCO}_{3}$, and 10 glucose) before initiation of recordings, except for low-calcium recordings where aCSF contained (in mM) $126 \mathrm{NaCl}, 3 \mathrm{KCl}, 1.25 \mathrm{NaH}_{2} \mathrm{PO}_{4}, 3.5 \mathrm{MgSO}_{4}, 0.5$ $\mathrm{CaCl}_{2}, 26 \mathrm{NaHCO}_{3}$, and 10 glucose.

Whole-cell patch-clamp recordings. BLA slices were transferred to a submersion-type recording chamber and perfused with room-temperature $\left(\sim 25^{\circ} \mathrm{C}\right) \mathrm{aCSF}(2.0 \mathrm{ml} / \mathrm{min})$ for whole-cell voltage-clamp recordings similar to previously published reports (Christian et al., 2013). Data were acquired via Axopatch 700B (Molecular Devices) and analyzed off-line via pClamp software (version 10.5, Molecular Devices) or miniature analysis software (Synaptosoft). Inclusion criteria for presumptive principal neurons included high membrane capacitance $(>100 \mathrm{pF})$ and low access resistance in the whole-cell configuration $(<20 \mathrm{M} \Omega$; Washburn and Moises, 1992). Cells in which access resistance or capacitance changed $\geq 20 \%$ during the record or with changes in resting membrane currents $\geq 100 \mathrm{pA}$ were excluded from analysis. Glutamatergic responses were pharmacologically isolated using $100 \mu \mathrm{M}$ picrotoxin $\left(\mathrm{a} \mathrm{GABA}_{\mathrm{A}}\right.$ antagonist) in the bath aCSF and were recorded with electrodes filled with an internal solution containing (in mM) 145 Cs-gluconate, 10 EGTA, 5 $\mathrm{NaCl}, 1 \mathrm{MgCl}_{2}, 10$ HEPES, 0.4 QX314, $1 \mathrm{CaCl}_{2}, 2 \mathrm{H}_{2} \mathrm{O}, 4 \mathrm{Mg}$-ATP, and $0.4 \mathrm{Na}_{3}$-GTP. Osmolarity of the internal solution was corrected to $\sim 285$ $\mathrm{mOsm}$ with sucrose, and $\mathrm{pH}$ was adjusted to $\sim 7.25$ with $\mathrm{D}$-gluconic acid. Synaptic responses were electrically evoked using concentric bipolar stimulating electrodes (FHC) placed either within the stria terminalis (medial stimulation) or external capsule (lateral stimulation) as indicated. Optogenetic synaptic responses were evoked using a $473 \mathrm{~nm}$ laser connected to a fiber optic cable; the naked end of the cable was placed just above the BLA. Five-millisecond laser pulses were used to activate channel rhodopsin found in PFC terminals, and pulse initiation and duration were controlled with a $5 \mathrm{~V}$ transistor-transistor logic potential delivered from the acquisition software. BLA spontaneous/miniature EPSCs (s/ mEPSCs) were recorded in the presence of $1 \mu \mathrm{M}$ tetrodotoxin (TTX). In experiments examining s/mEPSCs, event amplitude and interevent interval (IEI) were measured for 350 consecutive events within each cell, and median values were used for statistical comparisons between groups. Spontaneous event amplitudes below $5 \mathrm{pA}$ were rejected from the analysis based on the ability to differentiate these events from recording noise. We additionally analyzed the distribution of IEIs in $25 \mathrm{~ms}$ bins to determine whether strain-dependent differences in median values were related to a higher proportion of events occurring in "bursts" (IEIs <25 $\mathrm{ms}$ ), as they may summate to have more profound influence on the postsynaptic neuron compared with solitary sEPSCs. Similar analyses were performed for the s/mEPSC distributions.

\section{Drug preparation}

Stock solutions of phorbol 12,13-dibutyrate (PDBu; Sigma-Aldrich), TTX (Tocris), and 4-aminopyridine (4-AP; Tocris) were dissolved in standard aCSF, aliquoted, and stored at $-20^{\circ} \mathrm{C}$ until use. Picrotoxin (Tocris) and DNQX (Sigma-Aldrich) were prepared fresh daily, dissolved in DMSO, and added to aCSF with final concentrations of DMSO in the perfusate $<0.05 \%$. 


\section{Western blotting}

Western blot methods are similar to those reported previously (Christian et al., 2013). Each blot contained total BLA protein (one individual per lane) from D2 and B6 strains ( $n=8$ individuals per group) or mPFC protein from short hairpin RNA (shRNA) Munc13-2 and scrambled control animals ( $n=4$ individuals per group). shRNA Munc13-2 and scrambled control experiments with BLA tissue were performed in duplicate from unique cohorts. Group-specific expression was normalized to $\beta$-actin levels within that sample and expressed as "percent control" to facilitate comparisons across surgical cohorts. BLA and mPFC protein was prepared from tissue dissected from coronal slices, disrupted with sonication as described previously (Christian et al., 2012, 2013), and quantified in triplicate using the BCA assay (Thermo Fisher Scientific). On any given blot, the same mass of total protein was loaded for each strain or experimental condition. The specificity of individual antibodies was indicated by immunoreactive bands blocked by preincubation of antisera with peptide antigens when available or when they occurred at the expected molecular weights: Munc13-1 (catalog \#126 102, RRID: AB_2212687, Synaptic Systems), bMunc13-2 (catalog \#126 203, RRID: AB_2212701, Synaptic Systems), Munc18-1 (catalog \#8474, RRID: AB_10891779, Cell Signaling), pMunc18-1 ser515 (catalog \#PA14689, RRID: AB_2196829, Thermo Fisher Scientific), SNAP25 (catalog \#111 002, RRID: AB_2286328, Synaptic Systems), Syntaxin-1 (catalog \#AB5820, RRID: AB_2216165, EMD Millipore/Thermo Fisher Scientific), VAMP-1 (catalog \#ab3346, RRID: AB_303725, Abcam), VAMP-2 (catalog \#ab18014, RRID: AB_444187, Abcam), and VAMP-7 (catalog \#232 003, RRID: AB_2212953, Synaptic Systems). Immunoreactive bands were detected using standard chemiluminescent detection with an appropriate secondary antibody.

\section{Surgery}

Mice were kept under continuous isoflurane anesthesia (4\% for induction, $1.5 \%$ for maintenance) throughout the surgery, which consisted of bilateral injection ( $1 \mu$ l over 10 min per side) of an adeno-associated viral vector containing shRNA targeted to Munc13-2 (AAV5-GFP-U6mUNC13B-shRNA, Vector Biolabs) or a scrambled control vector (AAV5-GFP-U6-scrmb-shRNA, RRID: SCR_011010, Vector Biolabs). Channelrhodopsin (rAAV5/CamKII-hChR2(H134R)-EYFP from UNC GTC Vector Core, Chapel Hill, NC; RRID: SCR_002448) was coinjected in a subset of animals to confirm that terminals from $\mathrm{mPFC}$ projections to BLA were monosynaptic and glutamatergic. Mice were given $5 \mathrm{mg} / \mathrm{kg}$ ketoprofen subcutaneously at the conclusion of the surgery for pain management. The medial prefrontal cortex was targeted using a stereodrive (Neurostar) with the following coordinates: 1.78 AP, $\pm 0.33 \mathrm{ML}$, and 2.35 DV relative to bregma. Mice were pair housed after surgery and allowed 4-6 weeks to recover for virus expression before in vitro experiments.

\section{In silico analysis}

The GeneNetwork WebQTL database was queried to explore the inheritance pattern of candidate genes associated with presynaptic release characteristics in an array of BXD recombinant inbred mouse strains using the website www.genenetwork.org/webqtl/main.py. We selected BXD mice and searched published phenotypes with the search terms "presynaptic electrophysiology." We selected the record ID 13486 (Jansen et al., 2011) and used the mapping tool to identify chromosomal regions with high likelihood ratio statistics related to the synaptic phenotypes described in Results.

\section{Statistics}

All graphs are plotted as mean \pm SEM of each group. Primary statistical analyses were conducted using two-way ANOVA, one-way ANOVA, or $t$ tests (GraphPad, GraphPad Software) according to the experimental design as described, with post-tests as appropriate. Distributions of s/mEPSC interevent intervals and amplitudes were statistically analyzed by binning events into $25 \mathrm{~ms}$ (interevent interval) and $5 \mathrm{pA}$ (amplitude) bins above the $5 \mathrm{pA}$ cutoff for these analyses. Specific bins were then compared across strains with individual $t$ tests. The number of cells per group in each experiment are listed after each $p$ value in the format $n=$ D2/B6 or $n=$ shRNA/control.

\section{Results}

Spontaneous and miniature EPSC frequency is higher in BLA terminals of D2 mice

To examine basal glutamatergic transmission in these strains, we measured sEPSCs in BLA pyramidal cells using whole-cell patchclamp electrophysiology (Fig. 1). These recordings revealed that median IEIs were significantly shorter in D2 relative to B6 cells $(t$ test, $p=0.0235, n=7 / 6$ ) with no strain-dependent differences in median event amplitudes ( $t$ test, $p=0.249, n=7 / 6$ ), suggesting strain-dependent differences in presynaptic but not postsynaptic function. Distribution analysis of sEPSC IEIs revealed that the enhanced frequency of sEPSCs in D2 cells is driven by a higher proportion of events occurring with short IEIs (Fig. $1 A$; $t$ tests: 25 $\mathrm{ms}, p=0.0027 ; 100 \mathrm{~ms}, p=0.0345 ; n=7 / 6)$. For distributions of sEPSC amplitudes (Fig. 1B), sEPSC amplitudes were not significantly different between the strains across the distribution (5-85 pA, 5 pA bins). We next determined whether circuit-dependent effects contributed to the differences in sEPSC frequency by including $1 \mu \mathrm{M}$ TTX into the aCSF to block action potentials. Analysis of TTX-insensitive mEPSCs showed that D2 mice maintained significantly shorter median IEIs ( $t$ test, $p=0.0082, n=$ $9 / 7$ ) with no differences in the median event amplitude ( $t$ test, $p=0.9787, n=9 / 7)$, indicating that circuit-dependent effects did not contribute significantly to strain-dependent presynaptic differences. Distribution analysis of these mEPSC IEIs showed that D2 cells maintained a significantly higher proportion of events occurring with IEIs $\leq 100 \mathrm{~ms}$ (Fig. $1 D$; $t$ tests: $50 \mathrm{~ms}, p=$ $0.014 ; 75 \mathrm{~ms}, p=0.045 ; 100 \mathrm{~ms}, p=0.008 ; n=9 / 7)$. Similar analysis of the mEPSC event amplitude distributions (5 pA bins) did not reveal any significant differences between strains (Fig. 1E).

\section{Release probability is higher at two independent afferent pathways onto DBA BLA pyramidal cells}

To examine potential mechanisms controlling s/mEPSC frequency, we measured paired-pulse ratios as a proxy for release probability at BLA glutamatergic inputs. Considering that release probability is different across medial and lateral inputs to the BLA (Christian et al., 2013), we calculated paired-pulse ratios at both inputs using interstimulus intervals ranging from 25 to $500 \mathrm{~ms}$. These experiments revealed that D2 cells exhibited significantly lower paired-pulse ratios at lateral inputs across all interstimulus intervals (Fig. $2 A$; $t$ tests: $25 \mathrm{~ms}, p=0.0122, n=7 / 7 ; 50 \mathrm{~ms}, p=$ $0.0372, n=7 / 7 ; 250 \mathrm{~ms}, p=0.0359, n=8 / 7 ; 500 \mathrm{~ms}, p=0.0049$, $n=7 / 7)$ and at medial inputs during interstimulus intervals $<500 \mathrm{~ms}$ (Fig. $2 B$; $t$ tests: $25 \mathrm{~ms}, p=0.0195, n=8 / 8$; $50 \mathrm{~ms}, p=$ $0.0116, n=8 / 8 ; 250 \mathrm{~ms}, p=0.0392, n=8 / 8 ; 500 \mathrm{~ms}, p=0.7499$, $n=8 / 8$ ). These results suggest that increased glutamatergic presynaptic function at D2 BLA synapses is input independent and likely attributable to strain-specific differences in release probability.

\section{Calcium sensitivity of miniature EPSC release is higher in the B6 strain}

Release probability is determined by a number of factors in the presynaptic compartment that include both calcium-sensitive and calcium-insensitive processes. To determine how these processes potentially contribute to presynaptic differences, we recorded TTX-insensitive mEPSCs in reduced extracellular calcium using a modified aCSF. In these experiments, slices were incubated in either standard aCSF $\left(2 \mathrm{mM} \mathrm{Ca}^{2+}, 2 \mathrm{mM} \mathrm{Mg}^{2+}\right)$ or low-calcium aCSF $\left(0.5 \mathrm{~mm} \mathrm{Ca}^{2+}, 3.5 \mathrm{~mm} \mathrm{Mg}^{2+}\right)$ for at least $1 \mathrm{~h}$ 
A

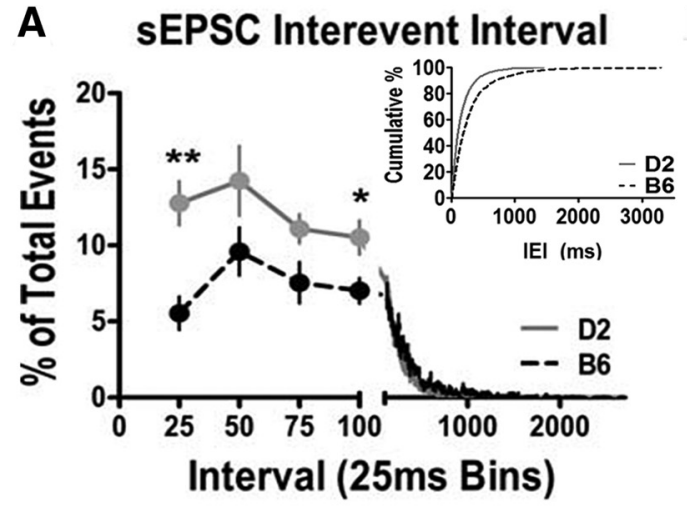

B

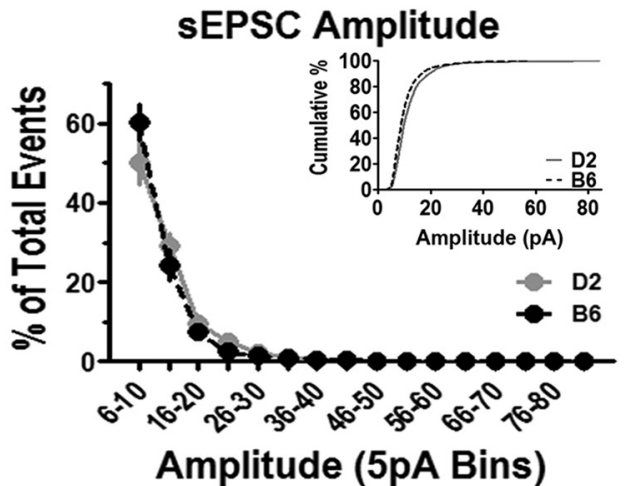

C
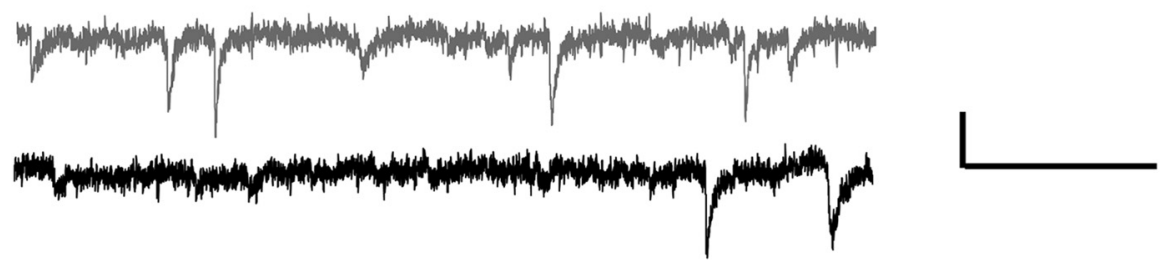

D mEPSC Interevent Interval

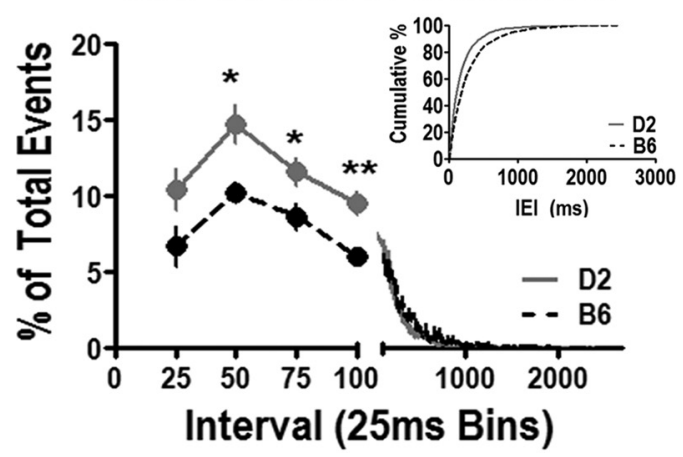

E

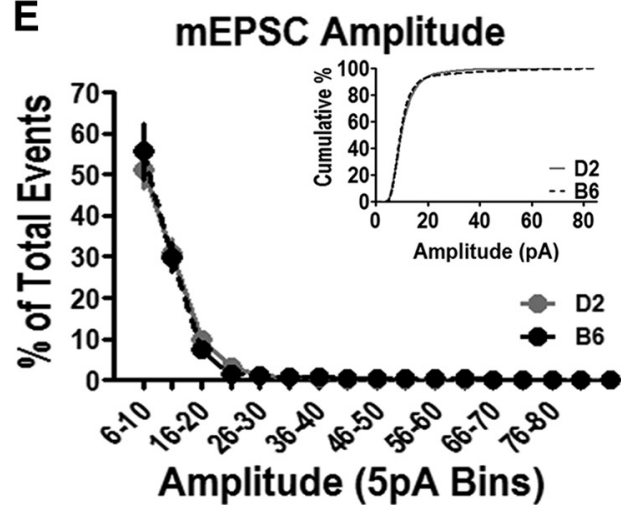

Figure 1. Spontaneous and miniature EPSCS. A, Distribution analysis of $\mathrm{SEPSCS}$ in $25 \mathrm{~ms}$ bins revealed that the enhanced frequency of vesicular release in D2 synapses is attributable to a higher proportion of events occurring at short interevent intervals ( $t$ tests; $25 \mathrm{~ms}^{* *} p=0.0027 ; 100 \mathrm{~ms},{ }^{*} p=0.0345 ; n=7 / 6$ ). The inset shows a cumulative probability plot for interevent intervals illustrating a leftward shift in D2 cells. B, sEPSC amplitude distribution illustrating no significant strain-dependent differences in the distribution of $5 E P S C$ amplitudes expressed in 5 pA bins. The inset shows a cumulative probability plot for amplitude illustrating no difference in amplitude distribution. C, Representative traces of sEPSCs in D2 (top, gray) and B6 (bottom, black) cells. Calibration: $5 \mathrm{pA}, 125 \mathrm{~ms}$. D, Distribution analysis of TTX-resistant mEPSCs in $25 \mathrm{~ms}$ bins revealed that enhanced frequency of vesicular release in D2 synapses is driven by a higher proportion of events occurring at short interevent intervals at presynaptic terminals ( $t$ tests; $50 \mathrm{~ms}^{,} p=0.0142 ; 75 \mathrm{~ms}^{*}{ }^{*} p=0.0453 ; 100 \mathrm{~ms},{ }^{* *} p=0.0044 ; n=9 / 7$ ). The inset shows a cumulative probability plot of interevent intervals illustrating a leftward shift in D2 cells. E, mEPSC amplitude distribution illustrating no strain-dependent difference in the distribution of mEPSC amplitudes (5 pA bins). The inset shows a cumulative probability plot for amplitude illustrating no difference in amplitude distribution.

before recording in these same solutions. Analysis of mEPSC median IEIs found that release from B6 terminals was inhibited by low extracellular calcium (intervals increased), whereas D2 terminal release appeared insensitive (Fig. $3 A$; two-way ANOVA: significant interaction, $p=0.0033$; main effects of calcium concentration, $p=0.0313$; main effects of strain, $p<0.0001$ : Bonferroni's post-test: $\mathrm{D} 2, t=0.6607, p>0.05 ; \mathrm{B} 6, t=3.855, p<$ 0.01 ; normal aCSF, $n=9 / 9$; low-calcium aCSF, $n=8 / 8$ ). Analysis of mEPSC IEI distributions revealed that low calcium specifically decreased the proportion of events occurring at short IEIs in B6 terminals (Fig. $3 C$; $t$ tests: $0-25 \mathrm{~ms}$ bin, $p=0.020 ; 26-50 \mathrm{~ms}$ bin, $p=0.007 ; 51-75 \mathrm{~ms}$ bin, $p=0.106 ; 76-100 \mathrm{~ms}$ bin, $p=0.0422$; $101-125 \mathrm{~ms}$ bin, $p=0.032$; $126-150 \mathrm{~ms}$ bin, $p=0.008)$. We found main effects of strain and calcium concentration on median mEPSC amplitude but no significant interaction, suggesting only modest strain-dependent postsynaptic effects of lowcalcium incubation (Fig. 3D; two-way ANOVA: significant main effects of calcium concentration, $p=0.0365$; significant main effects of strain, $p=0.0131$; no significant interaction, $p=$
0.1128; Bonferroni's post-test, $p<0.05$ in B6 only). Analysis of the amplitude distributions across $5 \mathrm{pA}$ bins likewise showed no significant impact of low extracellular calcium on D2 mEPSC amplitudes (Fig. 3E). However, for B6 synapses, the treatment caused a shift in the amplitude distribution toward smaller events (Fig. $3 F$ ) specifically by significantly decreasing the relative proportion of events in the $11-15 \mathrm{pA}(65.9 \pm 3.5 \%$ of events in $2 \mathrm{mM}$ $\mathrm{Ca}^{2+}$ vs $73.5 \pm 2.0 \%$ of events in $0.5 \mathrm{mM} \mathrm{Ca}^{2+} ; t$ test, $\left.p=0.004\right)$ and $16-20 \mathrm{pA}(23.5 \pm 2.6 \%$ vs $12.8 \pm 1.4 \%$; $p=0.035)$ bins. Although these data could suggest that contributions of calciumpermeable AMPA receptors expressed at B6 synapses might confound our IEI measures in this experiment, low extracellular calcium did not significantly alter the mEPSC area at either D2 $\left(51.6 \pm 4.2 \mathrm{pA} \cdot \mathrm{ms}\right.$ in $2 \mathrm{mM} \mathrm{Ca}_{\mathrm{o}}{ }^{2+}$ vs $53.3 \pm 7.6 \mathrm{pA} \cdot \mathrm{ms}$ in 0.5 $\left.\mathrm{mM} \mathrm{Ca}{ }_{\mathrm{o}}{ }^{2+} ; p=0.85\right)$ or $\mathrm{B} 6(55.2 \pm 3.1 \mathrm{pA} \cdot \mathrm{ms}$ vs $47.2 \pm 4.2$ $\mathrm{pA} \cdot \mathrm{ms} ; p=0.13$ ) synapses. Similarly, low calcium decreased B6 median mEPSC amplitudes by only $17 \%$ while increasing median IEI by over 33\%, suggesting these may be distinct effects of low calcium. 
A

$$
\text { Paired Pulse Ratio }
$$

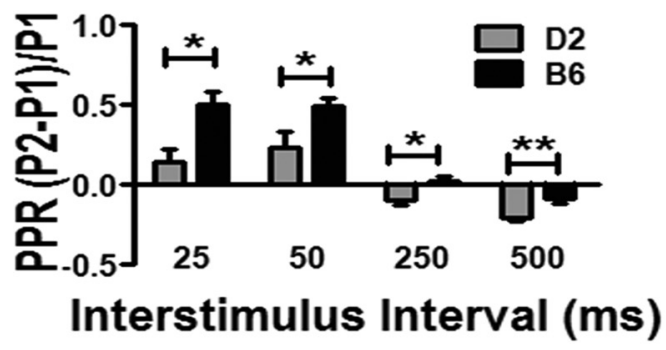

B Medial Inputs

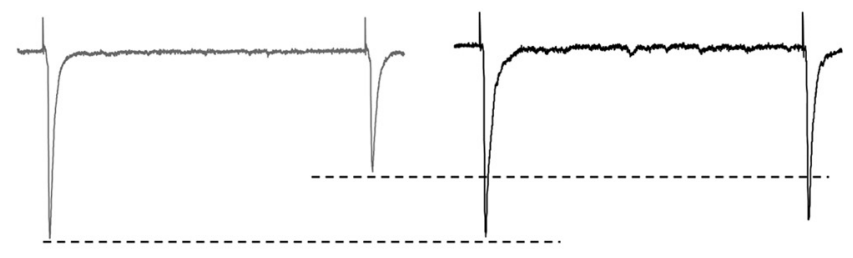

D

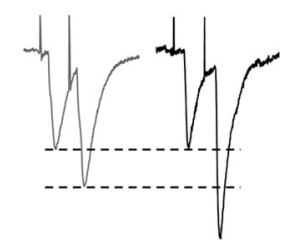
Paired Pulse Ratio

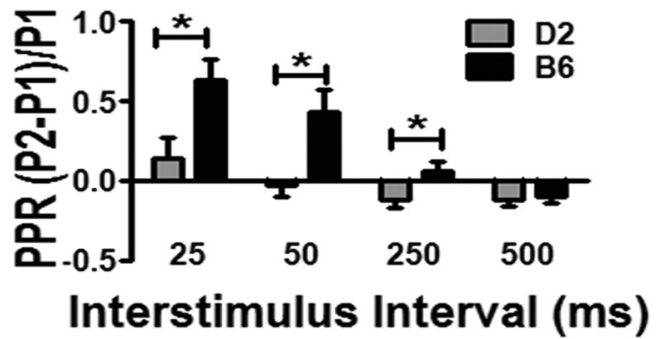

C
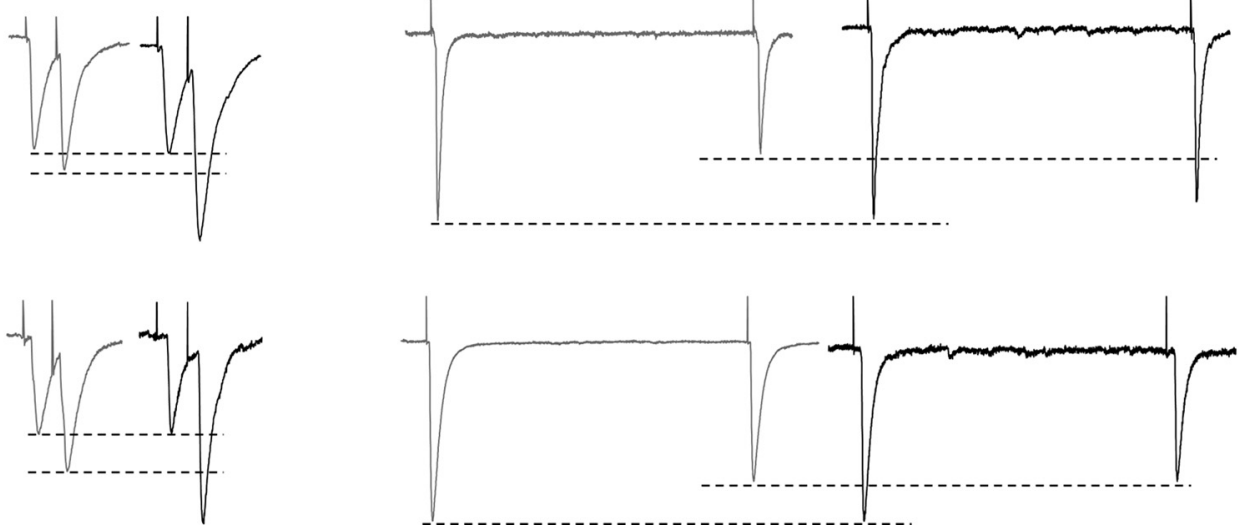

Figure 2. D2 synapses exhibit higher release probability at two distinct inputs to the BLA. $A$, Paired-pulse ratios at lateral inputs to the BLA were significantly lower in D2 relative to B6 cells ( $t$ tests; $\left.25 \mathrm{~ms}^{,}{ }^{*} p=0.0122, n=7 / 7 ; 50 \mathrm{~ms},{ }^{*} p=0.0372, n=7 / 7 ; 250 \mathrm{~ms}^{*}{ }^{*} p=0.0359, n=8 / 7 ; 500 \mathrm{~ms},{ }^{* *} p=0.0049 ; n=7 / 7\right) . B$, Paired-pulse ratios at medial inputs to the BLA were significantly lower in D2 relative to B6 cells ( $t$ tests; $\left.25 \mathrm{~ms},{ }^{*} p=0.0195, n=8 / 8 ; 50 \mathrm{~ms},{ }^{*} p=0.0116, n=8 / 8 ; 250 \mathrm{~ms},{ }^{*} p=0.0392, n=8 / 8 ; 500 \mathrm{~ms}, p=0.7499, n=8 / 8\right)$. C, Representative traces of paired-pulse stimulation at lateral inputs in D2 (gray) and B6 (black) cells at the $25 \mathrm{~ms}$ (left) and $500 \mathrm{~ms}$ (right) stimulus intervals. $\boldsymbol{D}$, Representative traces of paired-pulse stimulation at medial inputs in D2 (gray) and B6 (black) cells at $25 \mathrm{~ms}$ (left) $500 \mathrm{~ms}$ (right). The first pulses in each B6 trace are normalized to the first pulse in the corresponding D2 trace.

Bath application of phorbol esters significantly increases spontaneous release in $\mathrm{B} 6$ but not $\mathrm{D} 2$ cells

Calcium is a ubiquitous second messenger that is involved in the regulation of a wide variety of intracellular processes through interactions with different proteins and signaling molecules. Given that the synaptic phenotypes in B6 and D2 neurons suggest a presynaptic mechanism, we took advantage of our whole-cell recording configuration to reduce the impact of the biophysical properties of AMPA receptors and postsynaptic signaling cascades to evaluate potential calcium-sensitive intraterminal proteins, including components of the SNARE complex and presynaptic protein kinases like protein kinase $\mathrm{C}(\mathrm{PKC})$. We first measured sEPSCs during bath application of the phorbol ester $\operatorname{PDBu}(1 \mu \mathrm{M})$, which is a functional analog of the PKC coactivator diacylglycerol (DAG). We compared sEPSC IEI and amplitude recorded during a $5 \mathrm{~min}$ baseline period followed by bath application of PDBu for $15 \mathrm{~min}$. Here we found that the interevent interval of sEPSCs decreased after exposure to $1 \mu \mathrm{M}$ PDBu in B6 cells but not D2 cells (Fig. 4A; repeated-measures two-way ANOVA: main effects of PDBu exposure, $p=0.004$; main effects of strain, $p=0.02$; interaction, $p=0.064$ ). Bonferroni's post-test revealed that differences in sEPSC IEI were only significantly different after PDBu at B6 synapses $(t=5.107, p<0.001)$; this suggests that this PDBu treatment equalized sEPSC IEIs between D2 and B6 strains. Analysis of sEPSC IEI distributions within strain showed that PDBu exposure did not significantly alter the distribution recorded from D2 cells (Fig. 4B) but significantly enhanced the proportion of events that occurred at short IEIs in B6 cells (Fig. $4 E$; within-subject $t$ test: $0-25 \mathrm{~ms}$ bin, $p=0.001$;
$26-50 \mathrm{~ms}$ bin, $p=0.005 ; 51-75 \mathrm{~ms}$ bin, $p=0.036 ; 76-100 \mathrm{~ms}$ bin, $p=0.011)$. Median sEPSC amplitude was unaffected by phorbol ester treatment in both strains (Fig. 4D; repeatedmeasures two-way ANOVA: PDBu exposure, $p=0.617$; strain, $p=0.278$; interaction, $p=0.593$ ). This conclusion was supported by analysis of sEPSC amplitude distributions (Fig. 4C,F) that did not find any significant shift in the proportion of events at any of the amplitude bins in either strain.

To determine whether differences in PDBu sensitivity could reflect distinct presynaptic PKC activities in these mouse strains, rather than effects through other PDBu-sensitive targets, we used Western blotting to compare levels of a PKC-specific phosphorylation site on the Munc18-1 protein serine 515 (Sassa et al., 1996) as a proxy for presynaptic PKC function. Notably, we found that there were no differences in either the total levels of Munc18-1 (Fig. $5 C$; $t$ test, $p=$ 0.214 ) or in the relative level of phosphorylation of serine 515 in Munc18-1 (Fig. $5 D$; $t$ test, $p=0.773$ ) in these mouse strains. This suggested to us that the calcium- and $\mathrm{PDBu}$-sensitive presynaptic protein differentially expressed in B6 and D2 glutamatergic terminals was not related to PKC.

\section{In silico identification of Munc13-2 and differential} expression in B6 and D2 mice

B6 and D2 mice are the "founder" strains for a vast number of BXD inbred mouse strains. These strains have been used extensively to identify potential genetic regulators of complex cellular and behavioral responses, particularly phenotypes related to drugs of abuse. The WebQTL database (http://www. genenetwork.org/webqtl/main.py) is a repository for a large 


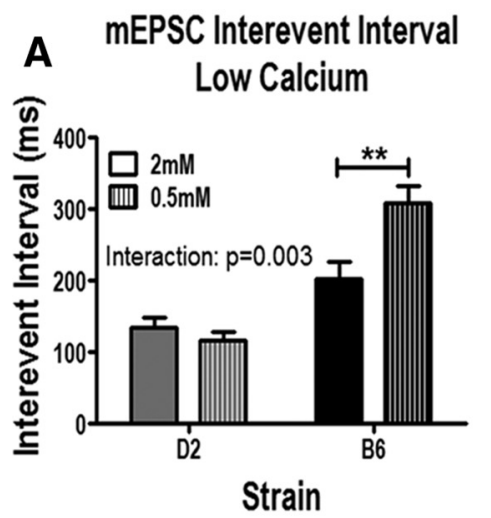

D

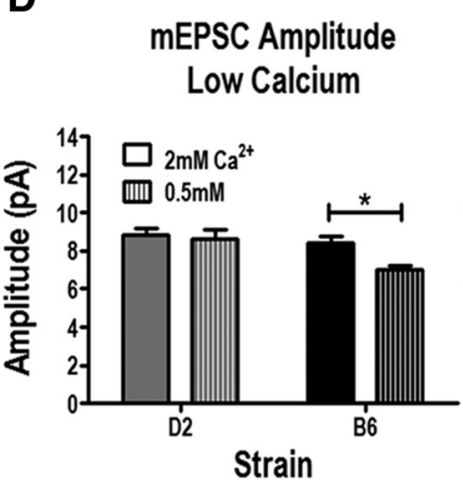

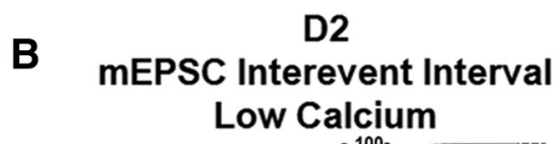

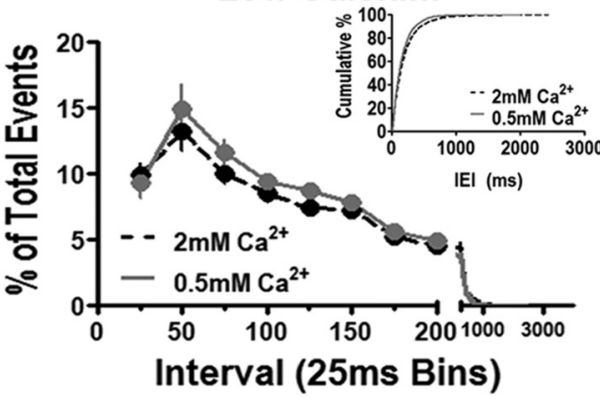

E

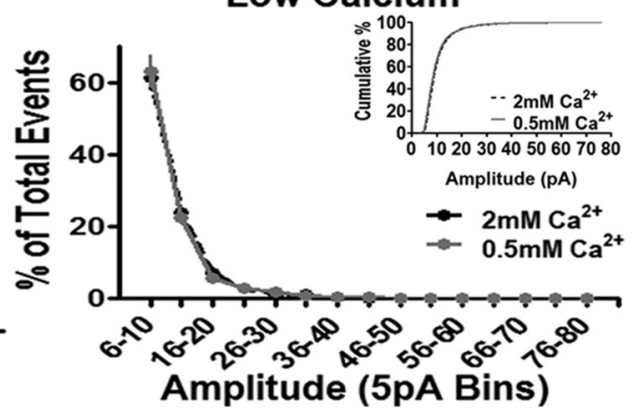

B6

\section{C mEPSC Interevent Interval Low Calcium}

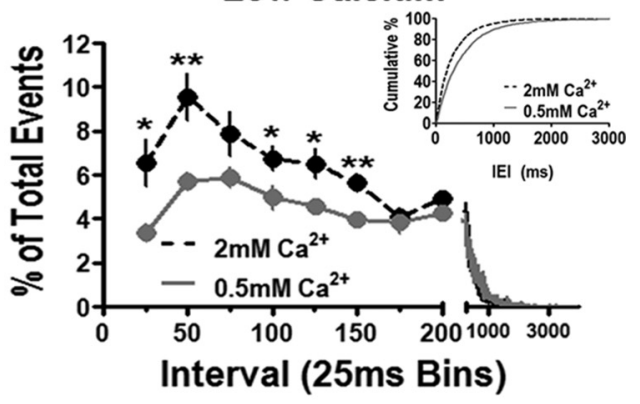

G

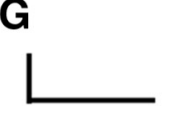

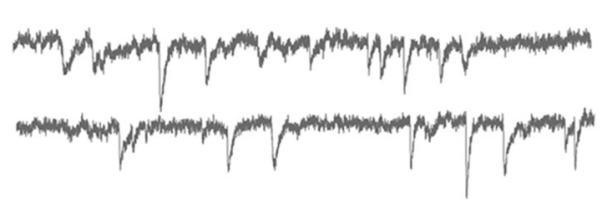

$2 \mathrm{mMCa}{ }^{2+}$

$0.5 \mathrm{mM} \mathrm{Ca}^{2+}$

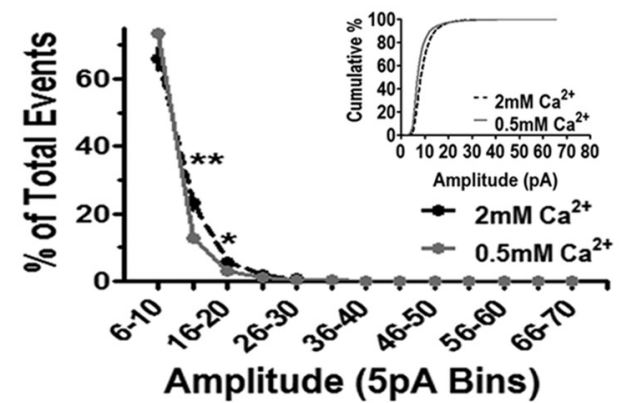

\section{B6 \\ mEPSC Amplitude Low Calcium \\ $\mathbf{F}$}

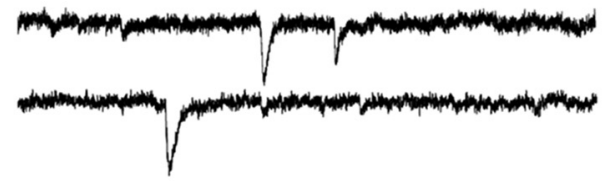

Figure 3. B6 but not $\mathrm{D} 2$ cells are sensitive to inhibition of $\mathrm{mEPSC}$ frequency in extracellular low-calcium aCSF. $A$, Median $\mathrm{mEPSC}$ interevent intervals recorded in standard aCSF ( $2 \mathrm{~mm}$ calcium) or low-calcium aCSF ( $0.5 \mathrm{~mm}$ calcium) revealed that $\mathrm{B} 6$ intervals were sensitive to inhibition by low-calcium conditions whereas D2 terminals were insensitive (2-way ANOVA: main effects of calcium concentration, $p=0.0313$; main effects of strain, $p<0.0001$; significant interaction, $p=0.0033$; Bonferroni's post-test: $\mathrm{D} 2, t=0.6607, p>0.05 ; \mathrm{B} 6, t=3.855$, ${ }^{* *} p<0.01 ;$ normal aCSF, $n=$ 9/9; low-calcium aCSF, $n=8 / 8$ ). $B$, Distribution analysis of mEPSC interevent intervals at D2 synapses found no significant differences across all interval bins. The inset shows a cumulative probability plot for interevent intervals illustrating no difference in event distribution in D2 cells. C, Distribution analysis of mEPSC interevent intervals found that extracellular calcium significantly modulated the short interval bins in B6 cells ( $t$ tests; $25 \mathrm{~ms}^{*}{ }^{*} p=0.020 ; 50 \mathrm{~ms}^{* * *} p=0.007 ; 100 \mathrm{~ms},{ }^{*} p=0.042 ; 125 \mathrm{~ms}^{*}{ }^{*} p=0.031 ; 150 \mathrm{~ms}^{*}{ }^{* *} p=0.008$ ). The inset shows a cumulative probability plot illustrating a rightward shift in IEI distribution in B6 cells. D., Median mEPSC amplitudes recorded in standard or low-calcium aCSF revealed strain-specific effects of low calcium on mEPSC amplitude (2-way ANOVA: significant main effects of calcium concentration, $p=0.0365$; significant main effects of strain, $p=0.0131$; no significant interaction, $p=0.1128 ;$ Bonferroni's post-test, ${ }^{*} p<0.05$ for B6 median amplitudes). $\boldsymbol{E}$, Distribution of mEPSC amplitudes (5 pA bins) in D2 cells was not significantly altered in extracellular low calcium. The inset shows a cumulative probability plot illustrating no change in amplitude distribution in D2 cells. $\boldsymbol{F}$, Analysis of mEPSC amplitude distributions for B6 synapses in extracellular low calcium found modest but significantly decreased contributions by events in from the $11-15 \mathrm{pA}$ and $16-20 \mathrm{pA}$ bins $\left(t \mathrm{test} ; 11-15 \mathrm{pA},{ }^{* *} p=0.003 ; 16-20 \mathrm{pA},{ }^{*} p=0.035\right)$. The inset shows a cumulative probability plot illustrating a slight leftward shift in amplitude distribution in B6 cells. G, Representative mEPSC traces recorded in standard aCSF (top) and low-calcium aCSF (bottom) in D2 (left, gray) and B6 (right, black) cells. Calibration: 5 pA, $125 \mathrm{~ms}$.

number of datasets describing the inheritance patterns of these phenotypes across many BXD inbred strains. Of particular interest for us is a recent publication (Jansen et al., 2011) that described the inheritance of hippocampal field EPSP characteristics across a large number of BXD strains and identified potential quantitative trait loci for various synaptic phenotypes. Notably, regions within chromosome 4 showed strong inheritance with respect to both spontaneous activity and oscillatory activity across multiple hippocampal subdivisions (38.9-44.2 Mb). Although the list of genes found within these regions is extensive and overlapping, only one gene, Unc13B (43.1 Mb), which encodes a protein (Munc13-2), binds both calcium and diacylglycerol/phorbol ester (Shin et al., 2010) and is found in the chromosomal region overlapping these synaptic phenotypes. Im- portantly, Munc13-2 also regulates release probability for a variety of glutamatergic synapses (Breustedt et al., 2010). This suggested to us that the unique synaptic phenotype expressed by B6 and D2 mice might be inherited as differences in Munc13-2 expression and/or function.

We subsequently probed BLA total protein for the expression of the Munc13 isoforms, Munc13-1 and bMunc13-2, which are the main Munc13 isoforms expressed in the cortical-like brain regions. These analyses revealed that the strains do not differ in the expression levels of the Munc13-1 isoform (Fig. 5B; $p=$ $0.753, n=8 / 8$ ), whereas bMunc13-2 expression is nearly two times higher in $\mathrm{B} 6$ cells compared with D2 cells (Fig. 5A; $p=$ $0.030, n=8 / 8)$. Other components of the SNARE complex and vesicle fusion machinery were likewise not differentially ex- 


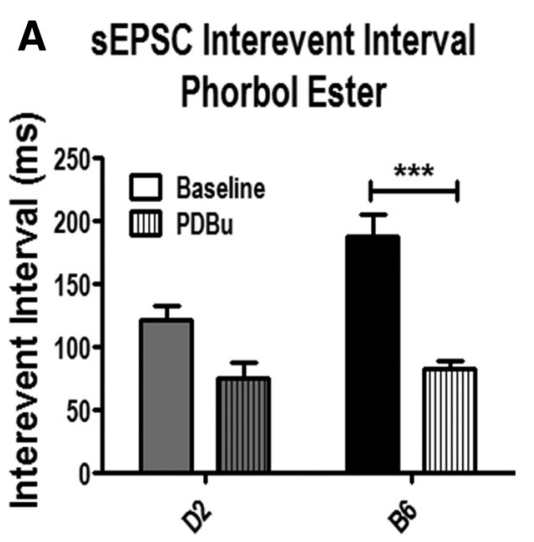

D
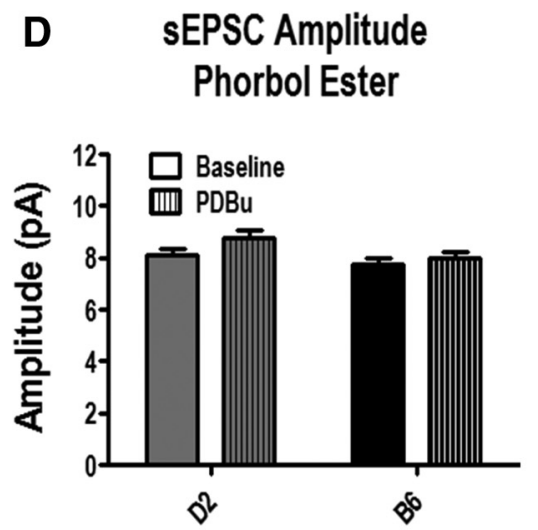

B

sEPSC Interevent Interval PDBu

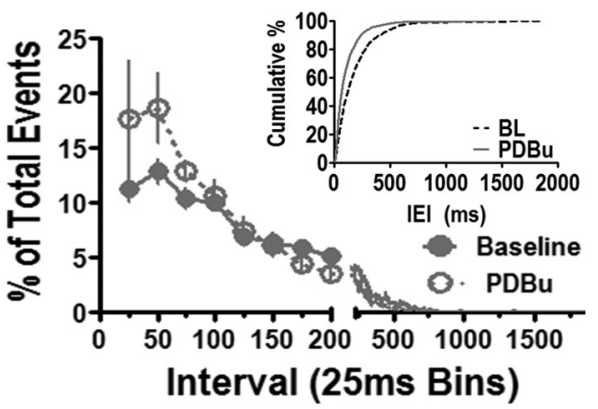

E
C

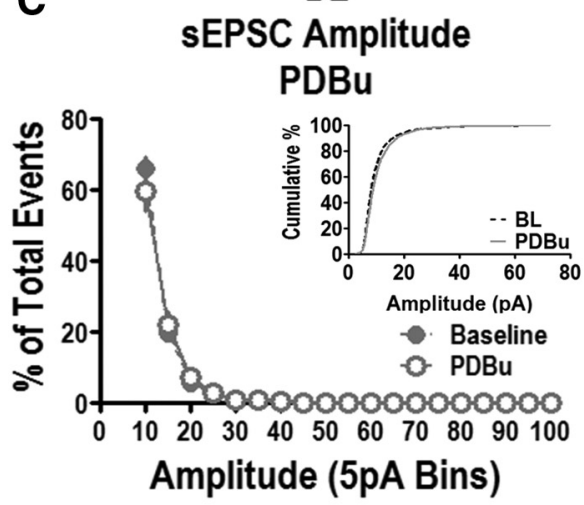

$\mathbf{F}$

B6

sEPSC Amplitude

PDBu

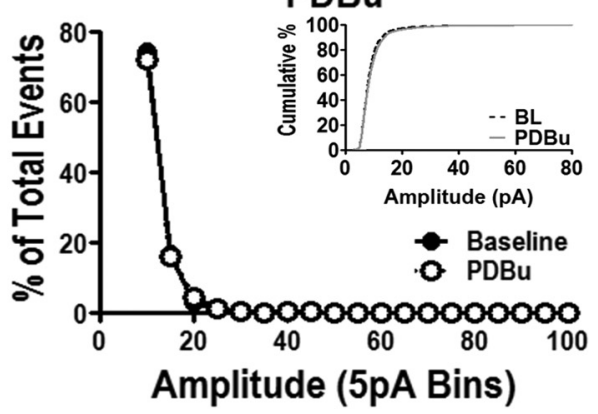

G
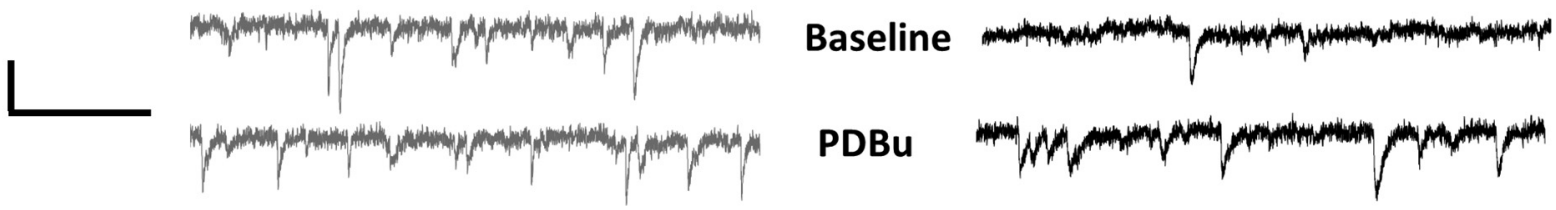

Figure 4. Phorbol ester application equalizes the frequency of sEPSCs in D2 and B6 synapses. $A$, Bath application of $1 \mu \mathrm{m}$ PDBu significantly decreases median sEPSC interevent intervals in B6 but not D2 synapses (repeated-measures 2-way ANOVA: significant main effects of PDBu exposure, $p<0.0001$; significant main effects of strain, $p=0.0274$; significant interaction, $p=0.0441$; Bonferroni's post-test: significant strain-dependent difference only at baseline, $t=3.781$, $\left.{ }^{* * *} p<0.001 ; n=6 / 6\right)$. B, C, Distribution analysis of D2 sEPSCs revealed no significant effects of PDBu exposure on either interevent interval $(\boldsymbol{B})$ or amplitude $(\boldsymbol{C}$ ), (within-subject $t$ test at each bin). The insets show cumulative probability plots of interevent intervals and amplitudes in D2 cells. $\boldsymbol{D}$, sEPSC amplitudes were not significantly altered by PDBu exposure (2-way ANOVA, no significant interaction or effects of strain and treatment). $\boldsymbol{E}$, Analysis of B6 sEPSC IEls revealed that PDBu significantly increased the proportion of events occurring at interevent intervals $\leq 100 \mathrm{~ms}$ (within-subject $t$ test; $0-25 \mathrm{~ms} \mathrm{bin},{ }^{* * *} p<0.001 ; 26-50 \mathrm{~ms}$ bin, ${ }^{* *} p<0.01 ; 51-75 \mathrm{~ms}$ bin, ${ }^{*} p<0.05 ; 76-100$ $\mathrm{ms}$ bin, $\left.{ }^{*} p<0.05\right)$. The inset shows a cumulative probability plot illustrating a large leftward shift in interevent interval distribution in B6 cells. $F$, Distribution analysis of B6 sEPSC amplitudes showing no significant effect of PDBu treatment across all amplitudes. The inset shows cumulative probability plot illustrating no change in amplitude distribution. $\mathbf{G}$, Representative traces sEPSCS in D2 (left, gray) and B6 (right, black) cells during baseline (top) and after 15 min of PDBu exposure (bottom). Calibration: 5 pA, 125 ms. BL, Baseline.

pressed in these samples, including SNAP25, Syntaxin-1, VAMP $1 / 2 / 7$, and complexin $1 / 2$ (Fig. $5 E-J$ ). This suggests that differential inheritance of Munc13-2 levels could convey the distinct presynaptic terminal phenotypes.

D2 cells can maintain release during longer stimulus trains than B6 cells

In part, Munc13 proteins control presynaptic release via regulation of vesicle priming and refilling of the readily releasable pool (RRP) of vesicles during repetitive stimulation. Both activities would directly influence release probability at glutamatergic synapses. We reasoned that differences in Munc13-2 levels in B6 and D2 mice should produce marked differences in one or both of these activities during prolonged stimulation. Considering that some synapses are capable of maintaining synaptic transmission during $2 \mathrm{~Hz}$ stimulation (Rizzoli and Betz, 2005) while others fatigue because of slower refilling of synaptic vesicles relative to release demands (Tani et al., 2014), we chose to use a $2 \mathrm{~Hz}$ stimulation for our initial experiments. In D2 cells, $2 \mathrm{~Hz}$ stimulation of the medial BLA inputs produced an initially facilitating response that only decayed near the end of the 15 min stimulation train (Fig. 6A). In contrast, B6 cells exhibited a more pronounced synaptic fatigue compared with D2 cells [cumulative amplitude, two-way ANOVA (Fig. 6A): significant main effects of stimulation, $p<0.0001$; significant main effects of strain, $p<0.0001$; significant interaction, $p<0.0001$; cumulative area, two-way ANOVA (Fig. $6 B$ ): significant main effects of stimulation, $p<$ 0.0001 ; significant main effects of strain, $p<0.0001$; significant interaction, $p=0.046]$. The rate at which synapses fatigue is controlled by both the size of the RRP and the rate at which this 
A

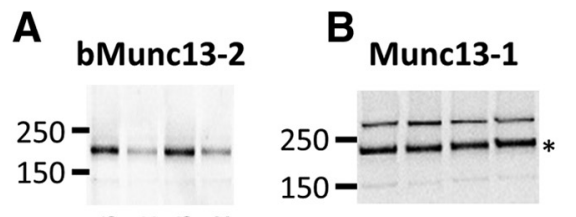

๓ำ ำ

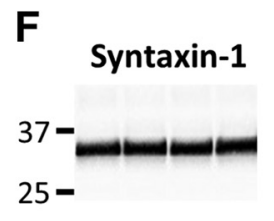

K
C
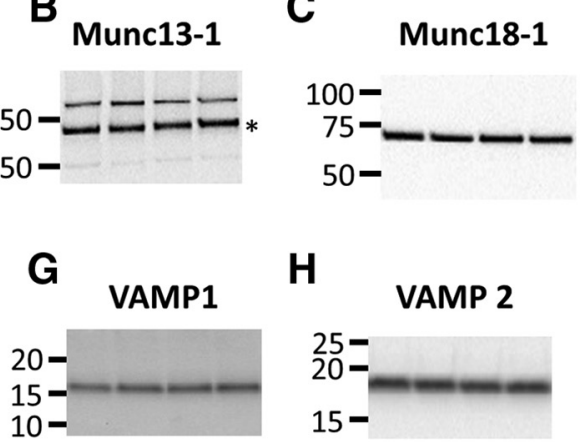

H

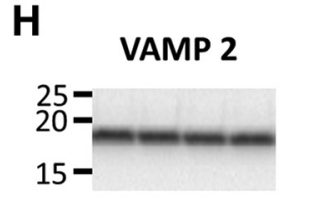

I

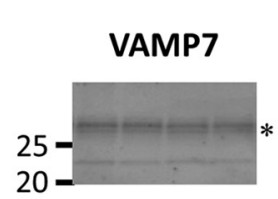

E
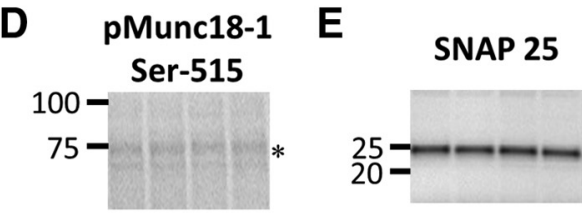

J Complexin $1 \& 2$

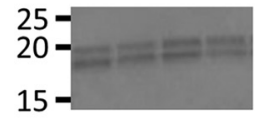

BLA

Protein Expression

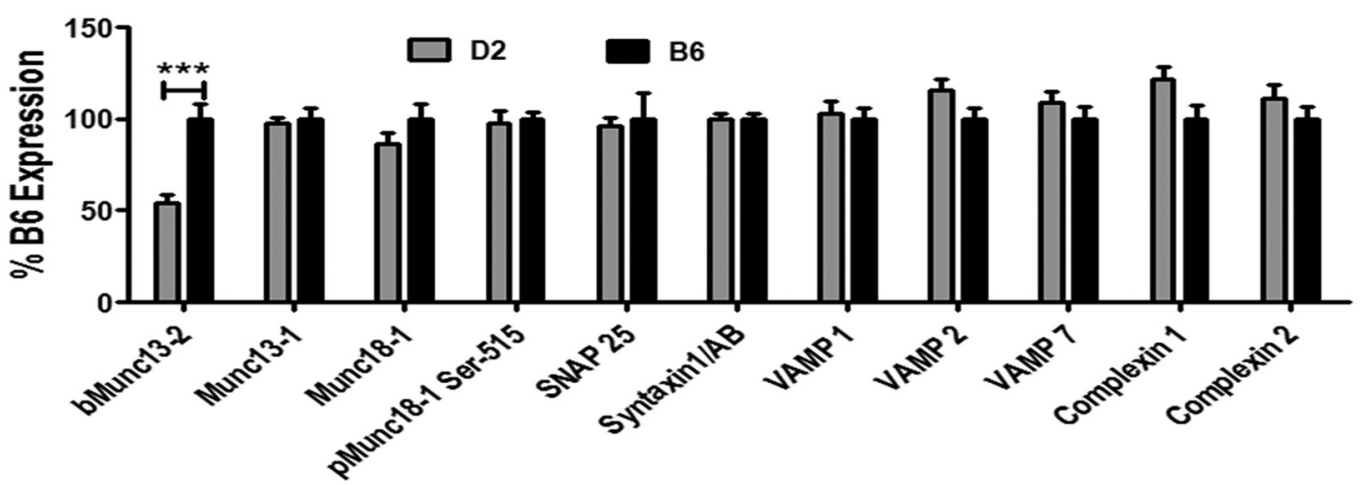

Figure 5. Western blots reveal strain-dependent differences in Munc13-2 expression in the BLA. $A$, The bMunc13-2 isoform is expressed significantly higher in the BLA of B6 than D2 mice ( $t$ test,

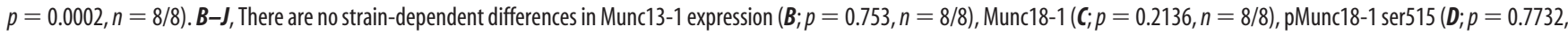
$n=8 / 8), \operatorname{SNAP25}(\boldsymbol{E} ; p=0.8031, n=8 / 8)$, Syntaxin-1 $(\boldsymbol{F} ; p=0.9976, n=8 / 8)$, VAMP1 $(\boldsymbol{G} ; p=0.7582, n=8 / 8), \operatorname{VAMP2}(\boldsymbol{H} ; p=0.0950, n=8 / 8)$, VAMP7 (I; $p=0.3424, n=8 / 8)$, Complexin $1(\boldsymbol{J}$; lower band, $p=0.0596, n=8 / 8$ ), and Complexin 2 (J; top band, $p=0.3004, n=8 / 8$ ). Asterisks in $\boldsymbol{B}, \boldsymbol{D}$, and $\boldsymbol{I}$ indicate the immunoreactive band of the appropriate molecular weight that was analyzed for expression level. The identity of weaker immunoreactive bands in these blots is unknown. $\boldsymbol{K}$, Summary graph showing BLA protein expression represented as percentage of the B6 strain $\left(t\right.$ test, $\left.{ }^{* * *} p<0.001\right)$.

pool is replenished. Thus, these data suggest that either the size of the RRP or the refilling/repriming rate is enhanced in D2 glutamatergic synapses relative to $\mathrm{B} 6$. To distinguish between these interpretations, we used a high-frequency $(40 \mathrm{~Hz})$ train that rapidly depletes the RRP, allowing for measurement of both the RRP and the vesicle recycling rate. Estimation of the RRP can be achieved through analysis of cumulative amplitude plots (Fig. $6 C$ ) during high-frequency stimulation by extrapolating the Y-intercept from a linear fit to the steady-state level achieved during the final $1 \mathrm{~s}$ of stimulation, and vesicle recycling can be assessed by subtracting the RRP size (in picoamperes) from the cumulative amplitude total (Schneggenburger et al., 2002). Using this analysis, we found that D2 synapses maintained higher levels of recycling relative to $\mathrm{B} 6$ synapses without differences in the size of the RRP (in picoamperes; Fig. 6E; two-way ANOVA: main effects of strain, $p=0.0026$; main effects of pool, $p<0.0001$; significant interaction, $p=0.0172$; Bonferroni's post-tests: RRP, $t=0.4982, p>0.05$; recycling pool, $t=3.985, p<0.001$ ).

\section{Post-tetanic potentiation of spontaneous EPSCs equalizes} frequency between strains

In addition to vesicle priming, Munc13 proteins help determine both the direction (facilitation or depression) and magnitude of short-term plasticity in presynaptic terminals (Lipstein et al., 2012). Here we measured a form of presynaptic short-term plasticity that occurs after repetitive stimulation and is referred to as augmentation or post-tetanic potentiation depending on the time course (Rosenmund et al., 2002). This plasticity is usually attributed to the accumulation of intraterminal calcium/calmodulin and DAG, which subsequently facilitate release probability (Lipstein et al., 2013) and can be measured as enhanced spontaneous release frequency immediately after stimulation (Eliot et al., 1994). We thus recorded sEPSCs from each strain immediately after $40 \mathrm{~Hz}$ stimulation of the medial BLA inputs. Median sEPSC IEIs post-tetanus were no longer different between strains after $40 \mathrm{~Hz}$ stimulation of the medial inputs ( $t$ test, $p=0.7958$ ). Furthermore, there were no differences in median sEPSC amplitude after $40 \mathrm{~Hz}$ stimulation ( $t$ test, $p=0.7190$ ). Analysis of IEI (Fig. $6 F$ ) and amplitude distributions (Fig. 6G) confirmed that straindependent differences were normalized post-tetanus. These data together suggest that differential expression of Munc13-2 may be responsible for the distinct presynaptic phenotypes expressed by these strains.

shRNA mediated knockdown of Munc13-2

To confirm that Munc13-2 isoform levels contribute to the disparate physiological profile of B6 and D2 mice, we used a shRNA to knock down the expression of Munc13-2. We injected either Munc13-2 shRNA or a scrambled control virus bilaterally into the mPFC of B6 mice and allowed 4-6 weeks for the virus to disrupt Munc13-2 expression in the mPFC-BLA terminals. We chose to inject the virus into the MPFC because of the well established role of prefrontal corticolimbic circuitry in fear-/anxietylike behaviors (Arruda-Carvalho and Clem 2014; Felix-Ortiz et 
A

\section{Cumulative Amplitude $2 \mathrm{~Hz}$ Medial Stimulation}

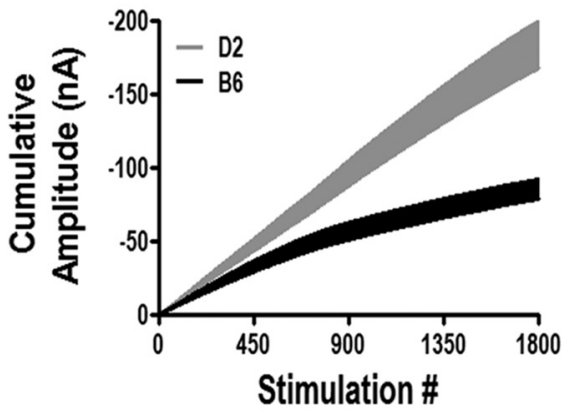

Cumulative Amplitude

C
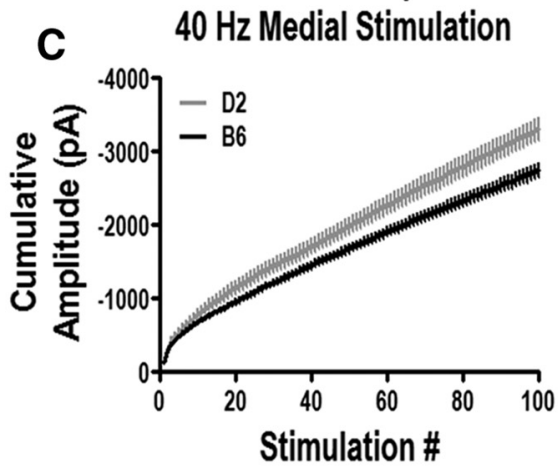

\section{RRP vs Recycling pool $40 \mathrm{~Hz}$ Medial Stimulation}
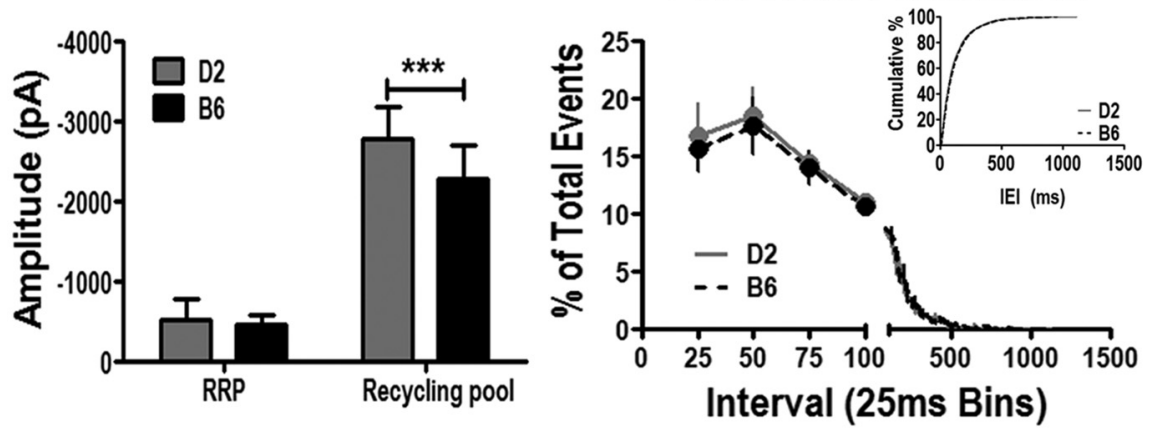

\section{G SEPSC Amplitude Post-Tetanic Stimulation}

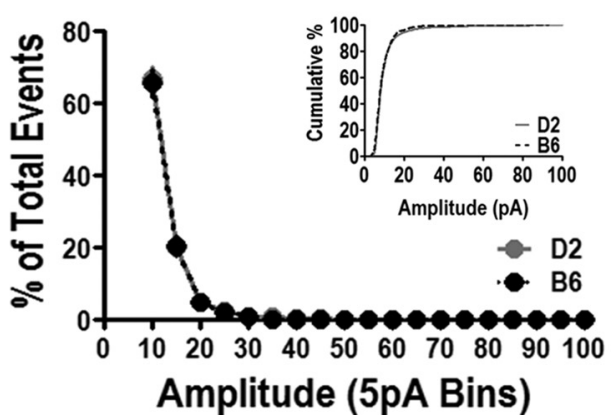

H
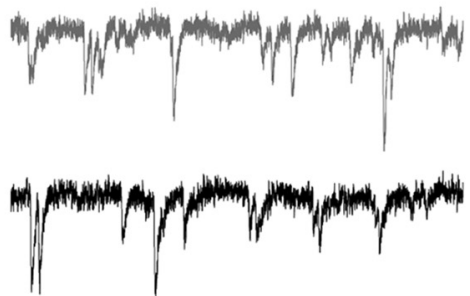

Figure 6. Strain-dependent differences in short-term plasticity at medial BLA inputs. $A$, Cumulative amplitude plot of a $15 \mathrm{~min}$ $2 \mathrm{~Hz}$ train in D2 and B6 cells. B, Cumulative area plot of a $15 \mathrm{~min} 2 \mathrm{~Hz}$ train in D2 and B6 cells. C, Cumulative amplitude plot of a $2.5 \mathrm{~s}$ $40 \mathrm{~Hz}$ train in D2 and B6 cells. D. Cumulative area plot of a $2.5 \mathrm{~s} 40 \mathrm{~Hz}$ train in D2 and B6 cells. E, Comparison of the size of the RRP versus the recycling pool in $D 2$ and $B 6$ cells found that $D 2$ cells maintained a higher recycling capacity compared with $B 6$ cells (2-way ANOVA: main effects of strain, $p=0.0026$; main effects of pool, $p<0.0001$; significant interaction, $p=0.0172$ al., 2015), because of their substantial contribution to medial inputs into the BLA (Sesack et al., 1989; Mcdonald et al., 1996; Dobi et al., 2013), and because the Munc13-2 isoform is predominantly expressed in frontal brain regions (Augustin et al., 1999). Western blot analysis revealed that the shRNA Munc13-2 construct, but not the control scrambled virus, significantly decreased Munc13-2 in both the B6 mPFC ( $t$ test, $p=0.0043$, $n=4 / 4$ ) and the BLA (Fig. $7 D$; $t$ test, $p=$ $0.0038, n=8 / 8$ ).

We next confirmed that the robust mPFC terminal fields to the BLA were represented in the electrically evoked synaptic responses using coinjection of Channelrhodopsin in some animals (Fig. $7 A, B$ ). These light-evoked responses were completely inhibited by perfusion of $1 \mu \mathrm{M}$ TTX (Fig. 7C). A concentration of $1 \mathrm{~mm} 4$-AP, which presumably prolonged Channelrhodopsinmediated presynaptic depolarization, reestablished light-evoked synaptic responses strongly, suggesting the lightevoked responses were monosynaptic. The responses recorded in TTX/4-AP were subsequently entirely inhibited by the AMPA/ kainate glutamate ionotropic receptor antagonist DNQX (20 $\mu \mathrm{m}$; Fig. 7C). We also found that light-evoked paired-pulse ratios were significantly lower in knockdown animals (Fig. $7 E ; ~ p=0.0356, n=4 / 5$ ), indicating that the manipulation increased release probability in BLA terminals. Subsequent whole-cell recordings of spontaneous events revealed that knockdown of mPFC Munc13-2 in B6 mice decreased median sEPSC IEIs relative to mice given injections of a scrambled control vector ( $t$ test, $p=$ $0.0003, n=11 / 14$ ), whereas median sEPSC amplitudes were unaltered by the manipulation ( $t$ test, $p=0.195, n=11 / 14$ ). Distribution analysis of sEPSC IEI bins revealed a virus-dependent significant difference in the proportion of events occurring at short interevent intervals (Fig. $7 F$; $t$ tests: $1-25 \mathrm{~ms}$ bin, $p=0.0009 ; 26-50 \mathrm{~ms}$ bin, $p=0.0048$; $51-75 \mathrm{~ms}$ bin, $p=0.0200 ; n=11 / 14)$. Analysis of sEPSC amplitude distributions con-

Bonferroni's post-tests: $\mathrm{RRP}, t=0.4982, p>0.05$; recycling pool, $\left.t=3.985,{ }^{* * *} p<0.001\right)$. RRP and recycling pool sizes were calculated as described in the text. $\boldsymbol{F}, \mathbf{G}$, Analysis of sEPSC interevent interval ( $\boldsymbol{F} ; 25 \mathrm{~ms}$ bins) and amplitude ( $\mathbf{G} ; 5 \mathrm{pA}$ bins) distributions recorded immediately after a $2.5 \mathrm{~s} 40 \mathrm{~Hz}$ train indicates that strain-dependent differences in IEl are normalized by a high-frequency tetanus. The insets show cumulative probability plots illustrating normalization of event distribution after tetanic stimulation. $\boldsymbol{H}$, Representative traces of sEPSC immediately after a $2.5 \mathrm{~s} 40 \mathrm{~Hz}$ train in D2 (top, gray) and B6 (bottom, black) cells. Calibration: 5 pA, 125 ms. 

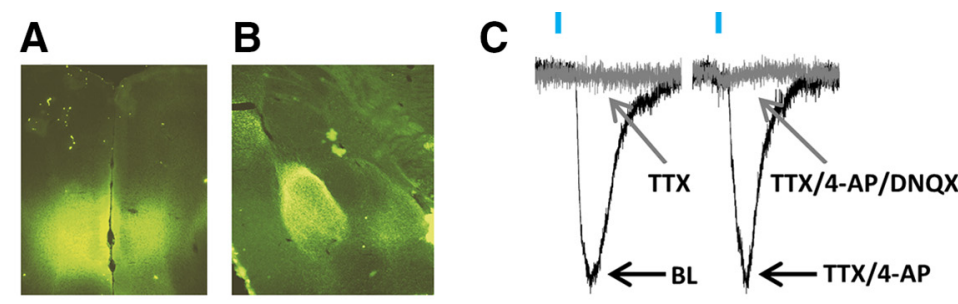

D

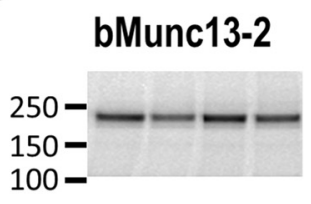

sEPSC Amplitude

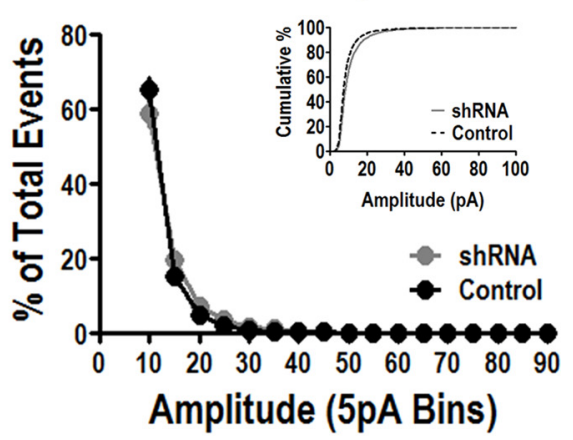

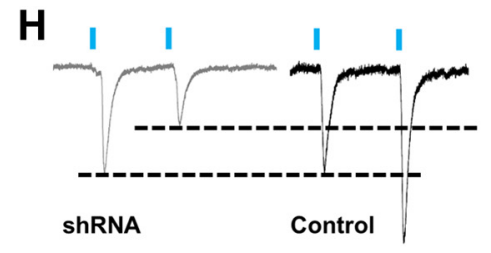

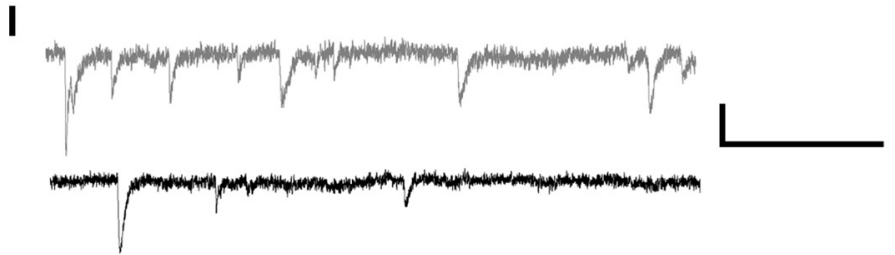

Figure 7. shRNA-mediated knockdown of Munc13-2 in mPFC increases sEPSC frequency in BLA. $\boldsymbol{A}$, Immunofluorescence of YFP expressed in the mPFC injection site. $\boldsymbol{B}$, Immunofluorescence of YFP arising from mPFC terminals in the BLA. C, Demonstration of monosynaptic glutamatergic transmission from mPFC to BLA. Optogenetic responses from the same cell at baseline (left, black) in the presence of $1 \mu \mathrm{m}$ TTX (left, gray) and the effects of $1 \mu \mathrm{m}$ TTX plus $1 \mathrm{~mm}$ 4-AP (right, black) in the presence of $1 \mu \mathrm{m}$ TTX plus $1 \mathrm{~mm}$ 4-AP plus $20 \mu \mathrm{m}$ DNQX (right, gray) are shown. D, shRNA targeted to the Munc13-2 isoform significantly decreased the expression of Munc13-2 protein in the BLA ( $p=0.0038, n=8 / 7)$. E, Optogenetic paired-pulse ratios were significantly lower in knockdown cells, indicating an increase in release probability ( $\left.{ }^{*} p=0.0356, n=4 / 5\right)$. $\boldsymbol{F}$, Distribution analysis of sEPSC interevent intervals in Munc13-2 knockdown (shRNA) versus scrambled control (control) BLA cells revealed an shRNA-dependent increase in the proportion of events occurring at short interevent intervals ( $t$ tests; $\left.25 \mathrm{~ms},{ }^{* * *} p=0.001 ; 50 \mathrm{~ms}^{, *} p=0.005 ; 75 \mathrm{~ms},{ }^{*} p=0.020 ; n=14 / 11\right)$. The inset shows a cumulative probability plot illustrating a leftward shift in event distribution in knockdown relative to control cells. G, sEPSC amplitude distributions show no shRNA-dependent differences in the distribution of sEPSC amplitudes. The inset shows a cumulative probability plot illustrating no difference in amplitude distribution. $\boldsymbol{H}$, Representative traces of light-activated paired-pulse stimulation in shRNA (left, gray) and scrambled control (right, black) cells. $I$, Representative traces of sEPSCs in shRNA (top, gray) and control (bottom, black) cells. Calibration: 5 pA, 125 ms.

firmed that manipulation of mPFC Munc13-2 expression did not alter the relative amplitude contributions across the range of bin sizes in our recordings (Fig. $7 G$ ).

Because of the relatively slow activation kinetics of this channelrhodopsin, we could not reliably evoke repeated synaptic events at interstimulus intervals $<50 \mathrm{~ms}$. Since these shorter intervals characterize the higher frequencies needed to deplete the readily releasable pool of synaptic vesicles, we used electrical stimulation to recruit afferent fibers, including those that originate from the mPFC. At $40 \mathrm{~Hz}$ stimulation (Fig. $8 \mathrm{~A}, \mathrm{~B}$ ), we found that $\mathrm{mPFC}$ terminals from shRNA-injected B6 mice expressed a higher recycling capacity than synapses from animals expressing control virus with no differences in the size of the RRP (Fig. $8 C$; two-way ANOVA: main effects of virus, $p=0.0163$; main effects of pool, $p<0.0001$; interaction, $p=0.121$; Bonferroni's posttest: RRP, $t=0.7401, p>0.05$; recycling pool, $t=3.057, p<$ $0.05 ; n=5 / 5)$. We then measured sEPSCs immediately after the $40 \mathrm{~Hz}$ stimulation and found that median sEPSC IEIs ( $t$ test, $p=$ $0.6768 ; n=5 / 5)$ and median sEPSC amplitudes ( $t$ test, $p=$ $0.0774 ; n=5 / 5$ ) were not significantly different after the stimulation train in shRNA and control synapses. This is similar to the post-tetanic "equalization" of event frequency in naive D2 and B6 synapses. Additionally, there were no significant differences in either the IEI or amplitude distributions of these events (Fig. $8 D, E)$. These results suggest that manipulation of a single protein, Munc13-2, was sufficient to produce a D2-like synaptic phenotype recorded from B6 BLA neurons.

\section{Discussion}

The D2 and B6 mouse strains are phenotypically different in a number of amygdala-related behaviors important for substance abuse, stress and anxiety, and learning and memory. Given the role of BLA in regulating these behaviors, we hypothesized that neurotransmission within the BLA would be different in D2 relative to B6 synapses. Consistent with this, we found that the D2 strain exhibited enhanced excitatory signaling within the BLA relative to $\mathrm{B} 6$ synapses. This was the result of increased presynaptic function in D2 synapses, as measured by enhanced sEPSC/ mEPSC frequency (Fig. 1) and increased release probability at two distinct afferent pathways (Fig. 2). It is noteworthy that TTX had only modest effects on either event intervals or amplitudes producing modest decreases in the relative frequency of "burstlike" events (IEIs <50 ms; compare Fig. 1 $A, D$ ) and larger EPSC amplitudes. This is consistent with our previous work and sug- 

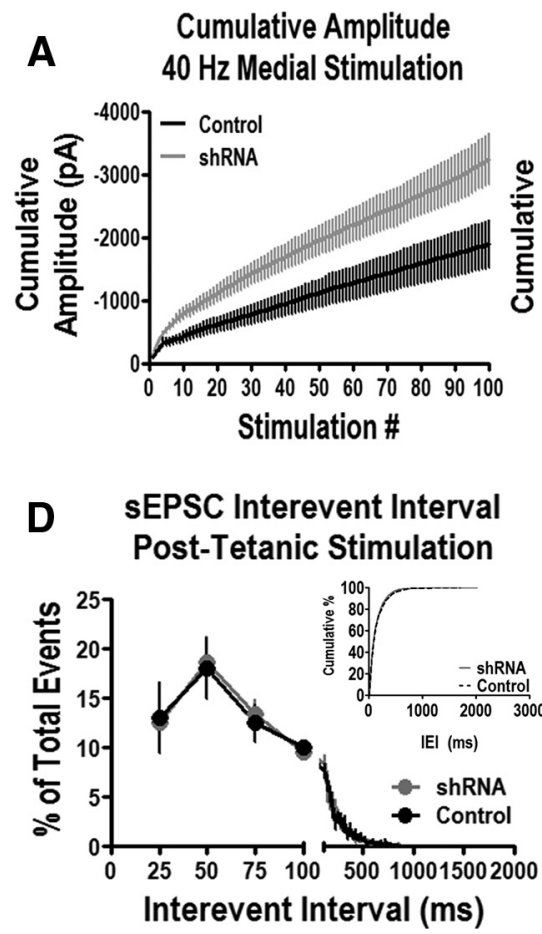

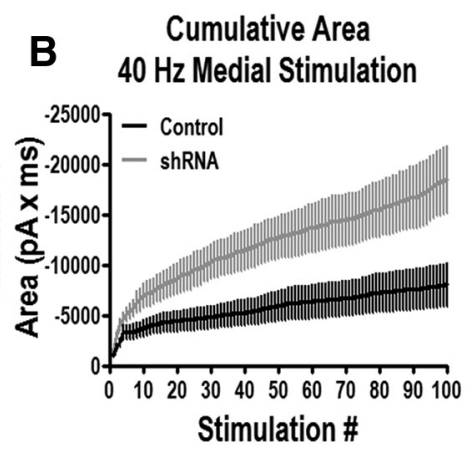

\section{RRP vs Recycling pool \\ $40 \mathrm{~Hz}$ Medial Stimulation}
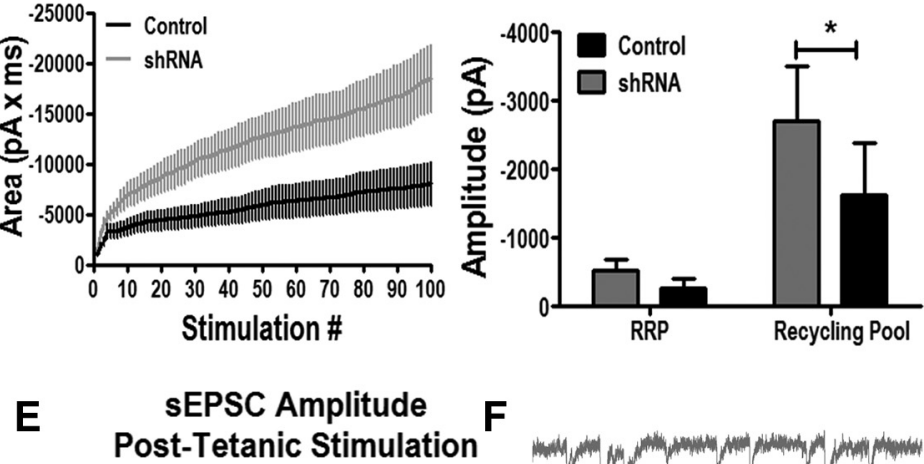

$\mathbf{F}$
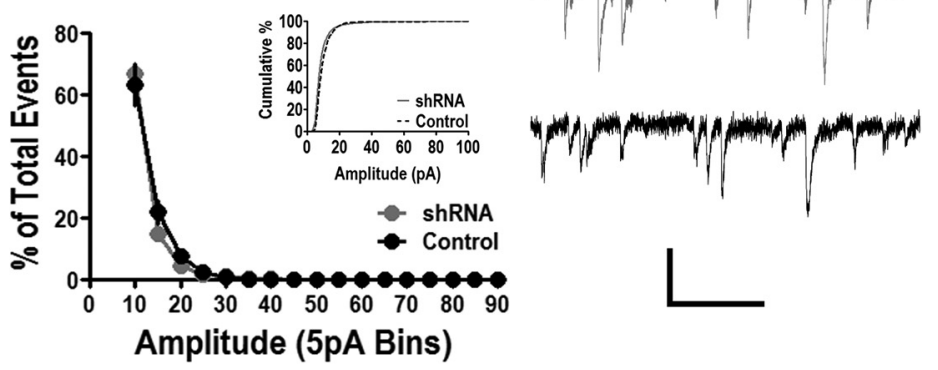

Figure 8. Munc13-2 knockdown alters short-term plasticity. A, Cumulative amplitude plot of a $2.5 \mathrm{~s} 40 \mathrm{~Hz}$ train recorded from B6 synapses expressing Munc13-2 shRNA or scramble control RNA. $B$, Cumulative area plot of a $2.5 \mathrm{~s} 40 \mathrm{~Hz}$ train in shRNA and control cells. C, Comparison of the size of the RRP versus the recycling pool in shRNA and control synapses found that shRNA maintained a higher recycling capacity compared with control (2-way ANOVA: main effects of virus, $p=0.0163$; main effects of pool, $p<0.0001$; Bonferroni's post-test: RRP, $t=0.7401, p>0.05 ;$ recycling pool, $\left.t=3.057,{ }^{*} p<0.05 ; n=5 / 5\right)$. D, E, Analysis of sEPSCs recorded immediately after a $2.5 \mathrm{~s} 40 \mathrm{~Hz}$ train revealed no shRNA-dependent differences in sEPSC interevent interval ( $\boldsymbol{D}$ ) or amplitude (E) distributions. The insets show corresponding cumulative probability plots. $\boldsymbol{F}$, Representative traces of sEPSCs immediately after a $2.5 \mathrm{~s} 40 \mathrm{~Hz}$ train shRNA (top, gray) and control (bottom, black). Calibration: 5 pA, $125 \mathrm{~ms}$.

gests that the majority of sEPSCs recorded from BLA pyramidal neurons represent unitary-like synaptic events.

Presynaptic function is dynamically regulated by a variety of molecular mechanisms including ion channels, presynaptic receptors, structural proteins, and priming-/release-related proteins (for review, see Craig and Boudin, 2001; Imig et al., 2014). These mechanisms regulate basal release probability and dictate the direction and magnitude of synaptic plasticity in response to neuronal activity and second-messenger signaling cascades. Fundamentally, these mechanisms can be segregated based on their sensitivity to intraterminal calcium concentration. We found that the miniature EPSCs in B6 terminals appeared more sensitive to presynaptic inhibition by low extracellular calcium than D2 terminals (Fig. 3). This suggests that a calcium-sensitive mechanism, likely localized within the presynaptic terminal given the whole-cell measurements, contributes to strain-dependent differences in presynaptic function. Proteins contributing to release probability include the synaptotagmins, Munc proteins, calmodulin, and PKC. Among these, only two, PKC and Munc13 proteins, are activated by the second-messenger diacylglycerol and its mimetic phorbol ester (PDBu). Importantly, $\mathrm{PDBu}$ application enhanced spontaneous release rates more robustly in B6 than D2 cells (Fig. 4A) and equalized the frequency of spontaneous release between strains, suggesting that a DAGdependent form of synaptic potentiation may be already engaged in D2 synapses. Given the strong conservation of amino acid sequences in the DAG-binding sites of PKC and Munc13 proteins, typical PKC antagonists that bind to and block the DAG interaction site on $\mathrm{PKC}$ also bind to Munc13 proteins and block their DAG-binding sites (Betz et al., 1998). Furthermore, PKC antagonists that inhibit the phosphate acceptor site on PKC, like chelerythrine chloride, appeared to be cytotoxic in our slice preparation after prolonged incubations. For these reasons, we examined both the phosphorylation status of a PKC-specific site found in presynaptic terminals (Ser515 on Munc18-1; Sassa et al., 1996) and the expression of Munc13 isoforms. There were no straindependent differences in either the expression level of total Munc18-1 protein or the level of phosphorylation at Ser515 (Fig. 5). This strongly suggests that basal differences in intraterminal PKC activity may not substantially contribute to these synaptic phenotypes. However, we did find nearly twofold higher expression of Munc13-2 protein in the BLA of B6 mice compared with the D2 strain (Fig. 5A), with no differences in Munc13-1 expression (Fig. 5B).

Munc13 proteins are large multidomain presynaptic scaffolding proteins that are essential for synaptic vesicle priming (Varoqueaux et al., 2002) and regulate presynaptic plasticity (Lipstein et al., 2012). All Munc13 isoforms contain a well conserved C-terminal Munc homology domain that interacts with Munc18-1/Syntaxin-1 heterodimers to facilitate SNARE complex formation as a prerequisite for vesicular release. Furthermore, significant differences in the $\mathrm{N}$-terminal regions between different isoforms alter the properties of presynaptic release and the characteristics of presynaptic plasticity. For example, Munc13-1 contains an N-terminal C2A domain that interacts with RIM proteins that are tethered to calcium channels. This interaction is believed to bring vesicles in close proximity to calcium channels near the presynaptic active zone, thus decreasing the amount of calcium entry required to initiate neurotransmitter release (Andrews-Zwilling et al., 2006). The bMunc13-2 isoform lacks this N-terminal C2A domain (Betz et al., 2001) and may prime vesicles at sites more distal to the active-zone calcium channels (Chen et al., 2015). These roles are consistent with the differential 
sensitivity to low extracellular calcium observed in B6 and D2 glutamatergic synapses; higher levels of Munc13-2 in B6 terminals would sequester a larger proportion of vesicles further from the active zone. Notably, the $\mathrm{C} 1$ domain of Munc13 proteins binds DAG, which both decreases the energy barrier for vesicle fusion and increases Munc13 membrane association (Rhee et al., 2002; Basu et al., 2007). Studies using knock-outs of the different Munc13 isoforms have found that synapses primed exclusively by Munc13-2 show greater facilitation by phorbol esters than synapses containing only Munc13-1 (Rosenmund et al., 2002). This is consistent with our observation that B6 synapses, which likely have a higher ratio of Munc13-2/Munc13-1 primed vesicles, exhibit increased sensitivity to the potentiating effects of phorbol esters (Fig. 4).

Within the calyx of Held, studies have found that Munc13-2 competitively limits the ability of Munc13-1 to stimulate calcium-dependent recovery of the RRP after periods of high neuronal activity (Chen et al., 2013). Consistent with these reports, B6 synapses were more vulnerable to synaptic rundown because of differences in the recycling rate and/or activitydependent refilling of the RRP (Fig. 6). Munc13 isoforms are also important for determining the direction and magnitude of shortterm plasticity after high synaptic activity attributable in part to their intrinsic differences in calcium-/calmodulin-binding sites (Lipstein et al., 2012). Immediately after high levels of synaptic activity, Munc13-2 and Munc13-3 isoforms are positively modulated by $\mathrm{Ca}^{2+} /$ calmodulin and enhance vesicle priming activity to produce a short-term enhancement of neurotransmission (Lipstein et al., 2012). Activity-dependent increases in intraterminal calcium facilitate levels of DAG, which can subsequently bind to Munc13 proteins to produce this augmentation. Consistent with this, we found that repetitive stimulation equalized the frequency of sEPSCs in B6 and D2 synapses (Fig. 6). Importantly, this included a facilitation of the burst-like release phenotype for events with intervals $<25 \mathrm{~ms}$ (Fig. $6 F$ ). This suggests that the presynaptic physiology of D2 cells may mimic a DAGpotentiated state because of lower Munc13-2 levels and preferential priming by the Munc13-1 isoform.

One way to determine the physiological role of Munc13-2 expression levels would be to examine other inbred mouse strains with similar expression profiles. However, these strains would likely maintain several different genetic mutations in other important presynaptic proteins, such as those that we probed for in Figure 5. Therefore, to determine whether Munc13-2 isoform levels contribute to the disparate presynaptic phenotypes expressed at D2 and B6 BLA excitatory synapses, we used a viral construct expressing a short hairpin RNA to knock down the expression of the Munc13-2 isoform in the mPFC of B6 mice. By manipulating Munc13-2 levels in B6 mice, we were able to directly assess the role of the Munc13-2 isoform in presynaptic physiology in the absence of other genetic confounds. The mPFC sends strong glutamatergic projections directly to BLA pyramidal cells (Fig. 6A,B; Vertes, 2004; Gabbott et al., 2005; Herry et al., 2008). Notably, these mPFC-BLA projections course through the ventromedial portions of the internal capsule and stria terminalis (Sesack et al., 1989; Mcdonald et al., 1996; Dobi et al., 2013), which were recruited during our electrical stimulation. This strategy also allowed us to control Munc13-2 levels in neurons that are presynaptic to the BLA cells. Using optogenetic stimulation, we determined that the $\mathrm{mPFC}$ makes monosynaptic glutamatergic projections to BLA pyramidal cells (Fig. 7C). Additionally, we found that light-evoked paired-pulse ratios of $\mathrm{mPFC}$ terminals in the BLA were significantly lower in Munc13-2 knockdown mice, indicating that the manipulation increased ve- sicular release probability (Fig. 7E). Furthermore, we found that Munc13-2 knockdown in the mPFC both increased sEPSC frequency and enhanced the frequency of burst-like spontaneous release (Fig. $7 F$ ). Additionally, this manipulation also increased the vesicle refilling rate during $40 \mathrm{~Hz}$ stimulation and occluded the effects of post-tetanic augmentation (Fig. 8C,D). Manipulation of mPFC Munc13-2 levels thus produced a physiological phenotype in B6 mice that was similar to that observed in D2 mice. These findings strongly implicate differential expression of Munc13-2 in the disparate synaptic physiology of D2 and B6 mice.

In summary, our data indicate that relative expression levels of Munc13 isoforms represent a heritable mechanism controlling unique synaptic physiology expressed by D2 and B6 mice. As these proteins are necessary for vesicular release, dictate characteristics of presynaptic plasticity, and show differences in regional expression, it is likely that this mechanism contributes to many of the behavioral differences between these strains. Although a number of potential mechanisms have been put forth to describe many of the strain-dependent behavioral differences, there is a clear theme that presynaptic signaling is differentially involved, suggesting that a common downstream mechanism may contribute to several of these behaviors. Importantly, the large number of modulatory domains present in Munc13 proteins may allow for precise manipulation of presynaptic function by novel pharmacotherapies.

\section{References}

Adamec RE, Blundell J, Collins A (2001) Neural plasticity and stress induced changes in defense in the rat. Neurosci Biobehav Rev 25:721-744. CrossRef Medline

Agnew-Blais J, Danese A (2016) Childhood maltreatment and unfavourable clinical outcomes in bipolar disorder: a systematic review and metaanalysis. Lancet Psychiatry 3:342-349. CrossRef Medline

Andrews-Zwilling YS, Kawabe H, Reim K, Varoqueaux F, Brose N (2006) Binding to Rab3A-interacting molecule RIM regulates the presynaptic recruitment of Munc13-1 and ubMunc13-2. J Biol Chem 281:1972019731. CrossRef Medline

Arruda-Carvalho M, Clem RL (2014) Pathway-selective adjustment of prefrontal-amygdala transmission during fear encoding. J Neurosci 34: 15601-15609. CrossRef Medline

Augustin I, Betz A, Herrmann C, Jo T, Brose N (1999) Differential expression of two novel Munc13 proteins in rat brain. Biochem J 337:363-371. CrossRef Medline

Basu J, Betz A, Brose N, Rosenmund C (2007) Munc13-1 C1 domain activation lowers the energy barrier for synaptic vesicle fusion. J Neurosci 27:1200-1210. CrossRef Medline

Betz A, Ashery U, Rickmann M, Augustin I, Neher E, Südhof TC, Rettig J, Brose N (1998) Munc13-1 is a presynaptic phorbol ester receptor that enhances neurotransmitter release. Neuron 21:123-136. CrossRef Medline

Betz A, Thakur P, Junge HJ, Ashery U, Rhee JS, Scheuss V, Rosenmund C, Rettig J, Brose N (2001) Functional interaction of the active zone proteins Munc13-1 and RIM1 in synaptic vesicle priming. Neuron 30:183196. CrossRef Medline

Breustedt J, Gundlfinger A, Varoqueaux F, Reim K, Brose N, Schmitz D (2010) Munc13-2 differentially affects hippocampal synaptic transmission and plasticity. Cereb Cortex 20:1109-1120. CrossRef Medline

Brigman JL, Mathur P, Lu L, Williams RW, Holmes A (2009) Genetic relationship between anxiety-related and fear-related behaviors in BXD recombinant inbred mice. Behav Pharmacol 20:204-209. CrossRef Medline

Chen Z, Cooper B, Kalla S, Varoqueaux F, Young SM Jr (2013) The Munc13 proteins differentially regulate readily releasable pool dynamics and calcium-dependent recovery at a central synapse. J Neurosci 33:83368351. CrossRef Medline

Chen Z, Das B, Nakamura Y, DiGregorio DA, Young SM Jr (2015) Ca2+ channel to synaptic vesicle distance accounts for the readily releasable pool kinetics at a functionally mature auditory synapse. J Neurosci 35: 2083-2100. CrossRef Medline 
Cho JH, Deisseroth K, Bolshakov VY (2013) Synaptic encoding of fear extinction in mPFC-amygdala circuits. Neuron 80:1491-1507. CrossRef Medline

Christian DT, Alexander NJ, Diaz MR, Robinson S, McCool BA (2012) Chronic intermittent ethanol and withdrawal differentially modulate basolateral amygdala AMPA-type glutamate receptor function and trafficking. Neuropharmacology 62:2430-2439. CrossRef Medline

Christian DT, Alexander NJ, Diaz MR, McCool BA (2013) Thalamic glutamatergic afferents into the rat basolateral amygdala exhibit increased presynaptic glutamate function following withdrawal from chronic intermittent ethanol. Neuropharmacology 65:134-142. CrossRef Medline

Crabbe JC (1998) Provisional mapping of quantitative trait loci for chronic ethanol withdrawal severity in BXD recombinant inbred mice. J Pharmacol Exp Ther 286:263-271. Medline

Craig AM, Boudin H (2001) Molecular heterogeneity of central synapses: afferent and target regulation. Nat Neurosci 4:569-578. CrossRef Medline

Dobi A, Sartori SB, Busti D, Van der Putten H, Singewald N, Shigemoto R, Ferraguti F (2013) Neural substrates for the distinct effects of presynaptic group III metabotropic glutamate receptors on extinction of contextual fear conditioning in mice. Neuropharmacology 66:274-289. CrossRef Medline

DuBois DW, Perlegas A, Floyd DW, Weiner JL, McCool BA (2006) Distinct functional characteristics of the lateral/basolateral amygdala GABAergic system in C57BL/6J and DBA/2J mice. J Pharmacol Exp Ther 318:629640. CrossRef Medline

Eliot LS, Kandel ER, Hawkins RD (1994) Modulation of spontaneous transmitter release during depression and posttetanic potentiation of Aplysia sensory-motor neuron synapses isolated in culture. J Neurosci 14:32803292. Medline

Elmer GI, Pieper JO, Hamilton LR, Wise RA (2010) Qualitative differences between $\mathrm{C} 57 \mathrm{BL} / 6 \mathrm{~J}$ and $\mathrm{DBA} / 2 \mathrm{~J}$ mice in morphine potentiation of brain stimulation reward and intravenous self-administration. Psychopharmacology (Berl) 208:309-321. CrossRef Medline

Felix-Ortiz AC, Burgos-Robles A, Bhagat ND, Leppla CA, Tye KM (2015) Bidirectional modulation of anxiety-related and social behaviors by amygdala projections to the medial prefrontal cortex. Neuroscience 321: 197-209. CrossRef Medline

Gabbott PL, Warner TA, Jays PR, Salway P, Busby SJ (2005) Prefrontal cortex in the rat: projections to subcortical autonomic, motor, and limbic centers. J Comp Neurol 492:145-177. CrossRef Medline

Gill K, Liu Y, Deitrich RA (1996) Voluntary alcohol consumption in BXD recombinant inbred mice: relationship to alcohol metabolism. Alcohol Clin Exp Res 20:185-190. CrossRef Medline

Grant BF, Saha TD, Ruan WJ, Goldstein RB, Chou SP, Jung J, Zhang H, Smith SM, Pickering RP, Huang B, Hasin DS (2016) Epidemiology of DSM-5 drug use disorder: results from the National Epidemiologic Survey on Alcohol and Related Conditions-III. JAMA Psychiatry 73:39-47. CrossRef Medline

Herry C, Ciocchi S, Senn V, Demmou L, Müller C, Lüthi A (2008) Switching on and off fear by distinct neuronal circuits. Nature 454:600-606. CrossRef Medline

Hwang BH, Kunkler PE, Tarricone BJ, Hingtgen JN, Nurnberger JI Jr (1999) Stress-induced changes of norepinephrine uptake sites in the locus coeruleus of $\mathrm{C} 57 \mathrm{BL} / 6 \mathrm{~J}$ and $\mathrm{DBA} / 2 \mathrm{~J}$ mice: a quantitative autoradiographic study using [3H]-tomoxetine. Neurosci Lett 265:151-154. CrossRef Medline

Imig C, Min SW, Krinner S, Arancillo M, Rosenmund C, Südhof TC, Rhee J, Brose N, Cooper BH (2014) The morphological and molecular nature of synaptic vesicle priming at presynaptic active zones. Neuron 84:416-431. CrossRef Medline

Jansen R, Timmerman J, Loos M, Spijker S, van Ooyen A, Brussaard AB, Mansvelder HD, Neuro-Bsik Mouse Phenomics Consortium, Smit AB, de Gunst M, Linkenkaer-Hansen K (2011) Novel candidate genes associated with hippocampal oscillations. PLoS One 6:e26586. CrossRef Medline

Kanatsou S, Ter Horst JP, Harris AP, Seckl JR, Krugers HJ, Joëls M (2016) Effects of mineralocorticoid receptor overexpression on anxiety and memory after early life stress in female mice. Front Behav Neurosci 9:374. CrossRef Medline

Lad HV, Liu L, Paya-Cano JL, Parsons MJ, Kember R, Fernandes C, Schalkwyk LC (2010) Behavioural battery testing: evaluation and behavioural outcomes in 8 inbred mouse strains. Physiol Behav 99:301-316. CrossRef Medline
Lipstein N, Schaks S, Dimova K, Kalkhof S, Ihling C, Kölbel K, Ashery U, Rhee J, Brose N, Sinz A, Jahn O (2012) Nonconserved $\mathrm{Ca}(2+) /$ calmodulin binding sites in Munc13s differentially control synaptic short-term plasticity. Mol Cell Biol 32:4628-4641. CrossRef Medline

Lipstein N, Sakaba T, Cooper BH, Lin KH, Strenzke N, Ashery U, Rhee JS, Taschenberger H, Neher E, Brose N (2013) Dynamic control of synaptic vesicle replenishment and short-term plasticity by $\mathrm{Ca}(2+)$-calmodulinMunc13-1 signaling. Neuron 79:82-96. CrossRef Medline

Maiya R, Kharazia V, Lasek AW, Heberlein U (2012) Lmo4 in the basolateral complex of the amygdala modulates fear learning. PLoS One 7:e34559. CrossRef Medline

McCool BA, Chappell AM (2015) Chronic intermittent ethanol inhalation increases ethanol self-administration in both C57BL/6J and DBA/2J mice. Alcohol 49:111-120. CrossRef Medline

Mcdonald AJ, Mascagni F, Guo L (1996) Projections of the medial and lateral prefrontal cortices to the amygdala: a Phaseolus vulgaris leucoagglutinin study in the rat. Neuroscience 71:55-75. CrossRef Medline

Milner LC, Shirley RL, Kozell LB, Walter NA, Kruse LC, Komiyama NH, Grant SG, Buck KJ (2015) Novel MPDZ/MUPP1 transgenic and knockdown models confirm Mpdz's role in ethanol withdrawal and support its role in voluntary ethanol consumption. Addict Biol 20:143-147. CrossRef Medline

Mozhui K, Karlsson RM, Kash TL, Ihne J, Norcross M, Patel S, Farrell MR, Hill EE, Graybeal C, Martin KP, Camp M, Fitzgerald PJ, Ciobanu DC, Sprengel R, Mishina M, Wellman CL, Winder DG, Williams RW, Holmes A (2010) Strain differences in stress responsivity are associated with divergent amygdala gene expression and glutamate-mediated neuronal excitability. J Neurosci 30:5357-5367. CrossRef Medline

Orsini C, Bonito-Oliva A, Conversi D, Cabib S (2005) Susceptibility to conditioned place preference induced by addictive drugs in mice of the C57BL/6 and DBA/2 inbred strains. Psychopharmacology (Berl) 181: 327-336. CrossRef Medline

Orsini C, Bonito-Oliva A, Conversi D, Cabib S (2008) Genetic liability increases propensity to prime-induced reinstatement of conditioned place preference in mice exposed to low cocaine. Psychopharmacology (Berl) 198:287-296. CrossRef

Pesold C, Treit D (1995) The central and basolateral amygdala differentially mediate the anxiolytic effects of benzodiazepines. Brain Res 671:213-221. CrossRef Medline

Przewłocka B, Vetulani J, Lasoń W, Dziedzicka M, Silberring J, Castellano C, Przewłocki R (1988) The difference in stress-induced analgesia in C57BL/6 and DBA/2 mice: a search for biochemical correlates. Pol J Pharmacol Pharm 40:497-506. Medline

Rhee JS, Betz A, Pyott S, Reim K, Varoqueaux F, Augustin I, Hesse D, Südhof TC, Takahashi M, Rosenmund C, Brose N (2002) Beta phorbol esterand diacylglycerol-induced augmentation of transmitter release is mediated by Munc13s and not by PKCs. Cell 108:121-133. CrossRef Medline

Rizzoli SO, Betz WJ (2005) Synaptic vesicle pools. Nat Rev Neurosci 6:5769. CrossRef Medline

Rosenmund C, Sigler A, Augustin I, Reim K, Brose N, Rhee JS (2002) Differential control of vesicle priming and short-term plasticity by Munc13 isoforms. Neuron 33:411-424. CrossRef Medline

Sajdyk TJ, Vandergriff MG, Gehlert DR (1999a) Amygdalar neuropeptide Y Y1 receptors mediate the anxiolytic-like actions of neuropeptide $\mathrm{Y}$ in the social interaction test. Eur J Pharmacol 368:143-147. CrossRef Medline

Sajdyk TJ, Schober DA, Gehlert DR, Shekhar A (1999b) Role of corticotropin-releasing factor and urocortin within the basolateral amygdala of rats in anxiety and panic responses. Behav Brain Res 100: 207-215. CrossRef Medline

Sanders SK, Shekhar A (1991) Blockade of GABAA receptors in the region of the anterior basolateral amygdala of rats elicits increases in heart rate and blood pressure. Brain Res 567:101-110. CrossRef Medline

Sanders SK, Shekhar A (1995) Regulation of anxiety by GABAA receptors in the rat amygdala. Pharmacol Biochem Behav 52:701-706. CrossRef Medline

Sassa T, Ogawa H, Kimoto M, Hosono R (1996) The synaptic protein UNC-18 is phosphorylated by protein kinase C. Neurochem Int 29:543552. CrossRef Medline

Schneggenburger R, Sakaba T, Neher E (2002) Vesicle pools and short-term synaptic depression: lessons from a large synapse. Trends Neurosci 25: 206-212. CrossRef Medline 
Sesack SR, Deutch AY, Roth RH, Bunney BS (1989) Topographical organization of the efferent projections of the medial prefrontal cortex in the rat: an anterograde tract-tracing study with Phaseolus vulgaris leucoagglutinin. J Comp Neurol 290:213-242. CrossRef Medline

Shin OH, Lu J, Rhee JS, Tomchick DR, Pang ZP, Wojcik SM, Camacho-Perez M, Brose N, Machius M, Rizo J, Rosenmund C, Südhof TC (2010) Munc13 C2B domain is an activity-dependent $\mathrm{Ca} 2+$ regulator of synaptic exocytosis. Nat Struct Mol Biol 17:280-288. CrossRef Medline

Stuber GD, Sparta DR, Stamatakis AM, van Leeuwen WA, Hardjoprajitno JE, Cho S, Tye KM, Kempadoo KA, Zhang F, Deisseroth K, Bonci A (2011) Excitatory transmission from the amygdala to nucleus accumbens facilitates reward seeking. Nature 475:377-380. CrossRef Medline

Tani H, Dulla CG, Farzampour Z, Taylor-Weiner A, Huguenard JR, Reimer RJ (2014) A local glutamate-glutamine cycle sustains synaptic excitatory transmitter release. Neuron 81:888-900. CrossRef Medline

Tarricone BJ, Hingtgen JN, Belknap JK, Mitchell SR, Nurnberger JI Jr (1995) Quantitative trait loci associated with the behavioral response of B x D recombinant inbred mice to restraint stress: a preliminary communication. Behav Genet 25:489-495. CrossRef Medline
Tsvetkov E, Carlezon WA, Benes FM, Kandel ER, Bolshakov VY (2002) Fear conditioning occludes LTP-induced presynaptic enhancement of synaptic transmission in the cortical pathway to the lateral amygdala. Neuron 34:289-300. CrossRef Medline

Varoqueaux F, Sigler A, Rhee JS, Brose N, Enk C, Reim K, Rosenmund C (2002) Total arrest of spontaneous and evoked synaptic transmission but normal synaptogenesis in the absence of Munc13-mediated vesicle priming. Proc Natl Acad Sci U S A 99:9037-9042. CrossRef Medline

Vertes RP (2004) Differential projections of the infralimbic and prelimbic cortex in the rat. Synapse 51:32-58. CrossRef Medline

Võikar V, Polus A, Vasar E, Rauvala H (2005) Long-term individual housing in C57BL/6J and DBA/2 mice: assessment of behavioral consequences. Genes Brain Behav 4:240-252. CrossRef Medline

Waddell J, Dunnett C, Falls WA (2004) C57BL/6J and DBA/2J mice differ in extinction and renewal of extinguished conditioned fear. Behav Brain Res 154:567-576. CrossRef Medline

Washburn MS, Moises HC (1992) Electrophysiological and morphological properties of rat basolateral amygdaloid neurons in vitro. J Neurosci 12: 4066-4079. Medline 